\title{
Article \\ Genome-Wide Association Study Reveals Genomic Regions Associated with Fusarium Wilt Resistance in Common Bean
}

\author{
Jean Fausto de Carvalho Paulino ${ }^{1}\left(\mathbb{D}\right.$, Caléo Panhoca de Almeida ${ }^{1}$, César Júnior Bueno ${ }^{2}$, Qijian Song ${ }^{3}$, \\ Roberto Fritsche-Neto ${ }^{4}$, Sérgio Augusto Morais Carbonell ${ }^{5}$, Alisson Fernando Chiorato ${ }^{5}$ \\ and Luciana Lasry Benchimol-Reis ${ }^{1, *}$ (1)
}

\section{check for}

updates

Citation: Paulino, J.F.d.C.; Almeida, C.P.d.; Bueno, C.J.; Song, Q.;

Fritsche-Neto, R.; Carbonell, S.A.M.; Chiorato, A.F.; Benchimol-Reis, L.L.

Genome-Wide Association Study Reveals Genomic Regions Associated with Fusarium Wilt Resistance in Common Bean. Genes 2021, 12, 765. https://doi.org/10.3390/genes12050765

Academic Editors: Anna M. Mastrangelo and Yong-Gu Cho

Received: 17 March 2021

Accepted: 13 May 2021

Published: 18 May 2021

Publisher's Note: MDPI stays neutral with regard to jurisdictional claims in published maps and institutional affiliations.

Copyright: (c) 2021 by the authors. Licensee MDPI, Basel, Switzerland. This article is an open access article distributed under the terms and conditions of the Creative Commons Attribution (CC BY) license (https:// creativecommons.org/licenses/by/ $4.0 /)$.
1 Centro de Recursos Genéticos Vegetais, Instituto Agronômico, Campinas 13075-630, SP, Brazil; jeanbiotec@gmail.com (J.F.d.C.P.); caleoalmeida@hotmail.com (C.P.d.A.)

2 Centro Avançado de Pesquisa em Proteção de Plantas e Saúde Animal, Instituto Biológico, Campinas 13101-680, SP, Brazil; cesar.bueno@sp.gov.br

3 Soybean Genomics and Improvement Laboratory, US Department of Agriculture, Agricultural Research Service (USDA-ARS), Beltsville, MD 20705, USA; qijian.song@usda.gov

4 Department of Genetics, 'Luiz de Queiroz' Agriculture College, University of Sao Paulo, Piracicaba 13418-900, SP, Brazil; roberto.neto@usp.br

5 Centro de Grãos e Fibras, Instituto Agronômico, Campinas 13075-630, SP, Brazil; sergio.carbonell@sp.gov.br (S.A.M.C.); alisson.chiorato@sp.gov.br (A.F.C.)

* Correspondence: luciana.reis@sp.gov.br

\begin{abstract}
Fusarium wilt (Fusarium oxysporum f. sp. phaseoli, Fop) is one of the main fungal soil diseases in common bean. The aim of the present study was to identify genomic regions associated with Fop resistance through genome-wide association studies (GWAS) in a Mesoamerican Diversity Panel (MDP) and to identify potential common bean sources of Fop's resistance. The MDP was genotyped with BARCBean6K_3BeadChip and evaluated for Fop resistance with two different monosporic strains using the root-dip method. Disease severity rating (DSR) and the area under the disease progress curve (AUDPC), at 21 days after inoculation (DAI), were used for GWAS performed with FarmCPU model. The $p$-value of each SNP was determined by resampling method and Bonferroni test. For UFV01 strain, two significant single nucleotide polymorphisms (SNPs) were mapped on the Pv05 and Pv11 for AUDPC, and the same SNP (ss715648096) on Pv11 was associated with AUDPC and DSR. Another SNP, mapped on Pv03, showed significance for DSR. Regarding IAC18001 strain, significant SNPs on Pv03, Pv04, Pv05, Pv07 and on Pv01, Pv05, and Pv10 were observed. Putative candidate genes related to nucleotide-binding sites and carboxy-terminal leucine-rich repeats were identified. The markers may be important future tools for genomic selection to Fop disease resistance in beans.
\end{abstract}

Keywords: Phaseolus vulgaris L.; Fusarium oxysporum f. sp. phaseoli; SNP markers; disease resistance; molecular breeding

\section{Introduction}

Common bean (Phaseolus vulgaris L.) originated in Mexico 4 to 6 million years ago [1] and was independently domesticated in Mesoamerica and the Andes 8000 years ago, constituting two main known gene pools [2]. Beans refers to legumes of the genus Phaseolus, family Fabaceae, subfamily Papilionoideae, tribe Phaseoleae, and subtribe Phaseolinae [3]. Common bean (Phaseolus vulgaris L.) is a diploid $(2 \mathrm{n}=2 \times=22)$, annual, predominantly self-pollinating species and one of the most important pulses worldwide [4,5].

Based on nucleotide sequences of chloroplasts, patterns of phaseolins, and genetic signatures in domesticated and wild accessions, it appears that the greatest genetic variation occurs among genotypes of the Mesoamerican gene pool, the most preferred type of bean for consumption in Brazil [6-9]. According to the FAO (Food and Agriculture Organization 
of the United Nations), global production of dry bean in 2018 was approximately 31.5 million tons. Brazil is considered the third largest producer in the world, with production of approximately 3.1 million tons [10]. The favorable edaphic and climatic conditions for growing common bean in Brazil allow wide distribution in every Brazilian state, with different harvest seasons, which is key for an annual supply [11].

An increase in planted area, especially under irrigation, combined with multiple crop seasons, has created conditions for high incidence of soil diseases, which are among the main causes of low crop yield and considerable losses [12]. One of the main fungal diseases, Fusarium wilt, is a severe vascular disease in common bean whose causal agent is Fusarium oxysporum Schlecht. f. sp. phaseoli Kendrick \& Snyder (Fop) [13,14]. The infection process begins in the roots, colonizes the xylem, and causes leaf wilt, vascular discoloration, chlorosis, dwarfism, and premature plant death $[15,16]$.

Therefore, it is necessary to identify potential bean sources of resistance to effectively control the pathogen. The development of resistant cultivars is a promising alternative for control of this disease as resistant cultivars are easily adopted by producers and do not cause environmental risks $[17,18]$. Pathogenicity testing through inoculation methods can be used to characterize the degree of pathogenicity of Fop strains [19]. Pathogenicity testing also provides an alternative for assessing the diversity of physiological races of the pathogen, the main cause of breakdown in genetic resistance to Fop in bean cultivars [20,21]. Currently, several definitions describe the complexity of genetic resistance of bean to Fop; some studies report it to be monogenic [22,23], some as oligogenic [24-26], and another as polygenic [17].

In common bean, only a limited number of studies have been conducted with the goal of clarifying the comprehension of the molecular mechanisms and pathways involved in bean response to Fop's infection [27]. Recent results demonstrate by Chen et al. [27] using whole transcriptome and metabolome of common bean infected by Fop shows the response to Fop uses different and effective defense pathways comprising of a complex resistance network of structural, signaling, hormonal and chemical responses.

An alternative for understanding genetic control of bean resistance to Fop, how resistance loci are distributed in the bean genome, and the intensity of their effects is to study them indirectly, through their association with genetic markers [28,29]. Among the preferred genetic markers, single nucleotide polymorphisms (SNPs) are noteworthy, since these markers can be integrated with the QTN (Quantitative Trait Nucleotide) responsible for phenotypic variation in the trait of interest [30].

The GWAS using natural populations have higher mapping resolution than linkage mapping and greater cost-effectiveness [31]. In GWAS, the recombination events accumulated over innumerable generations reduce linkage disequilibrium (LD), allowing more precise estimates of the location of genes of interest to be obtained [32]. In recent years, GWAS has been widely used to investigate the genetic architecture of complex characteristics in model plants such as Arabidopsis thaliana [33], soybean [34,35], and common bean $[36,37]$.

In the current study, a total of 2001 high-quality single-nucleotide polymorphisms (SNPs) distributed over the 11 bean chromosomes were genotyped using SNP Assay technology (Illumina BARCBean6K_3 BeadChip) [38]. The BARCBean6K_3 BeadChip has successfully contributed to the study of several traits in beans [39-44]. This technology has also been used in the identification of genomic regions associated with disease resistance, such as common mosaic virus [45], anthracnose [41], root rot [46], rust [42], angular leaf spot [47], and to fusarium wilt [25].

The aim of the present study was to identify new genomic regions associated with Fop resistance in a Mesoamerican Diversity Panel (MDP) and, taking into account the phenotypical evaluations, identify potential genotypes of common bean as sources for Fop's resistance. 


\section{Materials and Methods}

\subsection{Plant Material}

A total of 205 common bean genotypes of Mesoamerican origin with characteristics of agronomic interest mainly concerning disease resistance and the technological quality of the bean grain were selected from the germplasm bank (BAG) of the Agronomic Institute (IAC, Campinas, SP, Brazil) to represent the MDP. These accessions were chosen taking into account the genetic characterization of Mesoamerican accessions that had been carried out in advance $[37,48]$.

In Brazil, there is a greater preference for Mesoamerican beans [49]. The MDP includes accessions that were released by common bean breeding programs form different institutions in Brazil, both private and governmental. Altogether, 131 genotypes belonging to the Carioca commercial class, validated in advance by GWAS [37]. In addition, 30 genotypes from the Black commercial class, and 44 genotypes from the Special class including 'Pinto', 'Cream', 'Mottled', 'Mulatinho', 'Rose', 'Red' 'Light Pink', 'Brown', 'Light brown', 'Yellow', 'Red' (Table S1).

\subsection{DNA Extraction, Genotyping and SNP Calling}

The total genomic DNA of each sample from the MDP was extracted from young leaves using the CTAB protocol [50]. The quality of the DNA was confirmed by electrophoresis in 1\% agarose and quantified by the Qubit fluorimeter (Thermo Fisher, Waltham, MA, USA). All samples were diluted to a concentration of $50 \mathrm{ng} \cdot \mu \mathrm{L}^{-1}$. Genotyping was performed using the BeadChip BARCBean6K_3 technology with 5398 SNPs [38]. The BARCBean6K_3 was developed based on the first common bean genome (i.e., Phaseolus vulgaris v1), and subsequently, the flanking sequences of each SNPs were blasted (e.g., BLASTN) against the most current reference genome, Phaseolus vulgaris v2.1 [51], and the position of each SNP was obtained. The SNP calling and genotypic data obtained were analyzed for quality using the Genome Studio 2.0 software (Illumina, San Diego, CA, USA).

The genotype matrix was converted into HapMap format, with the reference allele represented by " $\mathrm{A}$ ", the alternative allele by " $\mathrm{G}$ ", the heterozygous allele by " $\mathrm{R}$ ", and the missing data by " $\mathrm{N}$ " using the TASSEL 5.0 software [52]. For the quality control, SNPs with MAF (Minor Allele Frequency) smaller than 0.05, heterozygosity, and missing data greater than 0.10 were removed. Finally, markers not positioned in the genome were also removed, and " $\mathrm{N}$ " loci were imputed using the Beagle 5.0 software [53]. After the quality control filters, 2001 high-quality SNPs were selected for association mapping.

\subsection{Inoculation and Evaluation of Fop Strains in Common Beans}

The 205 MDP genotypes were evaluated for Fop resistance under greenhouse conditions in a randomized complete block design. Each genotype was replicated three times. A replicate was represented by one plastic pot with dimensions of $11 \times 8 \times 9 \mathrm{~cm}^{3}$ containing two plants of a single genotype, for a total of six repetitions evaluated for each genotype. The genotypes were planted in 128-cell trays containing sterile vermiculite.

Among the genotypes, IAC Milênio was used as a Fop-resistant check cultivar and BRS Estilo as a susceptible check cultivar [19]. Two strains of Fop were used. The first (UFV01 strain) was collected from the Meia Noite cultivar in Coimbra, Minas Gerais, Brazil [14] and the second (IAC18001 strain) was obtained from the A211 cultivar in Campinas, São Paulo, Brazil. Both strains were purified through a single spore from cultures previously confirmed as new races of Fop [54,55].

The inocula were produced on PDA (potato-dextrose-agar) medium incubated for 10 days in a growth chamber at $24 \pm 1{ }^{\circ} \mathrm{C}$ with a 12 -h photoperiod. The spore suspension was prepared one hour before inoculation at the concentration of $1 \times 10^{6}$ conidia $\mathrm{mL}^{-1}$, including macro and microconidia [56].

Ten days after sowing, the roots of each genotype were washed using distilled water and a third of the length was cut using a sterile scissor (the root-dip method, Paulino et al. [19]. The roots were immediately immersed in a Falcon ${ }^{\circledR}$ tube containing ten $\mathrm{mL}$ of 
the spore suspension for five minutes. The roots of the control cultivars were immersed in autoclaved water for the same time. The plants were transplanted to a plastic pot containing the substrate Biomix ${ }^{\circledR}$, followed by the addition of $10 \mathrm{~mL}$ of inoculum, and kept in a greenhouse until the time of evaluation. The plants were irrigated daily, and each pot was fertilized with $0.3 \mathrm{~g}$ urea as $\mathrm{N}$ source at ten DAI.

After the appearance of the first symptoms, at $14 \mathrm{DAI}$, evaluations were performed at 15, 18, and 21 DAI, with equal intervals between evaluations. The DSR was measured according to an adapted scale [56], with values ranging from 1 to 9: score $1=$ absence of symptoms and discoloration in the hypocotyl; score 3 = chlorosis, wilt, and restricted necrosis of the first leaves of the plant, with slight discoloration in the hypocotyl; score $5=$ chlorosis, wilt, and necrosis in the leaves below the pointer and intermediate discoloration in the hypocotyl; score 7 = severe symptoms of generalized wilting throughout the plant, and dwarfism and severe discoloration in the hypocotyl; and score $9=$ dead plant (Figure 1). The genotypes were classified according to resistance to the strain using the following criteria: resistant-scores from 1 and 3; moderately resistant-scores from 3.1 to 6.0; and susceptible—-scores from 6.1 to 9.0 .

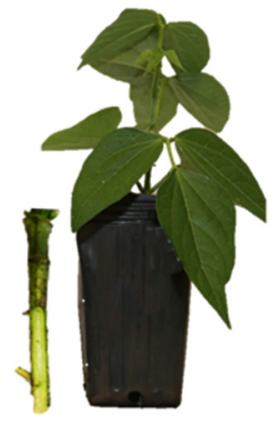

1

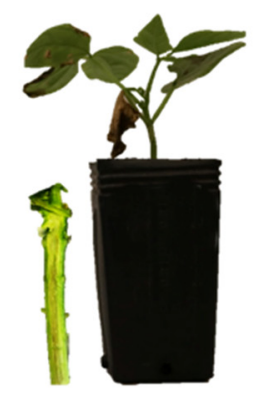

3

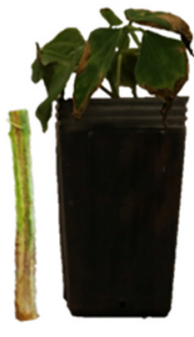

5

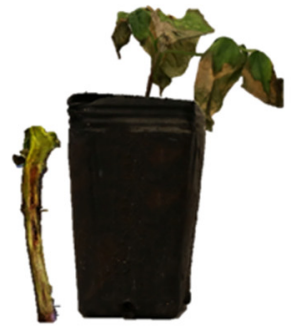

7

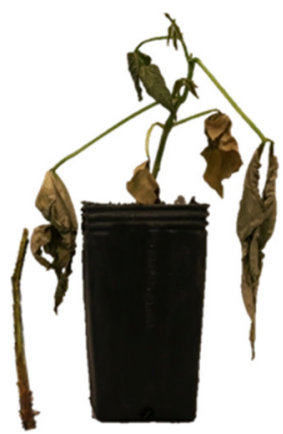

9

Figure 1. The DSR was measured according to an adapted scale [56], with values ranging from 1 to 9: score $1=$ absence of symptoms and discoloration in the hypocotyl; score 3 = chlorosis, wilt, and restricted necrosis of the first leaves of the plant, with slight discoloration in the hypocotyl; score $5=$ chlorosis, wilt, and necrosis in the leaves below the pointer and intermediate discoloration in the hypocotyl; score 7 = severe symptoms of generalized wilting throughout the plant, and dwarfism and severe discoloration in the hypocotyl; and score $9=$ dead plant.

The disease severity data for all evaluations for each genotype were used to calculate the AUDPC by Shaner and Finney [57] according to the formula:

$$
A U D P C=\sum_{i=1}^{n}\left[\left(\frac{Y_{i+1}+Y_{i}}{2}\right)\left(T_{i+1}+T_{i}\right)\right]
$$

where

$Y_{i}=$ severity of Fop at the $i$ th observation,

$T_{i}=$ time (DAI) at the $i$ th observation and

$n=$ total number of evaluations.

\subsection{Statistical Analysis and Prediction of Genotipic Values}

The DSR and AUDPC were compared using Pearson correlation at 21 DAI. The linear mixed model applied was:

$$
\text { Trait }(D S R, A U D P C)=\text { accession }+ \text { block }+ \text { error }
$$

The assumptions of normal errors and homogeneous error variance were checked. In a first step, we carried out analysis of deviance (ANADEV) by the likelihood ratio test (LRT) method. The linear mixed model was used, and in a first step, the broad-sense 
heritability and accession effect vector that was considered as random. In a second step, the accession effect vector was considered as fixed, and the phenotypic matrix was given by the genotypic values estimated by the Restricted Maximum Likelihood/Best Linear Unbiased Estimator-REML/BLUE of the Be-Breeder package [58]. The genotypic values for each accession and trait were used as input phenotypic data in association mapping analysis.

\subsection{Genome-Wide Association Studies}

A fixed and random model Circulating Probability Unification-FarmCPU—was used in GWAS [59]. The package explores the MLMM (multi-locus mixed-model) and performs analysis in two interactive steps: a fixed-effect model (FEM) is applied first, followed by a random-effect model (REM), so that both are repeated interactively until no significant SNP is detected. To avoid type I errors (i.e., false positives), the structuring matrix was tested using the Bayesian Information Criterion (BIC) test according to Schwarz [60] for a regular mixed linear model available in GAPIT 2.0 [61] with the first five components of the PCA. The population structure of MDP (structure results derived from PCA and BIC test) and the relatedness to Kinship (heatmap) [62] were included in the GWAS model.

The limit of the $p$-value of each SNP was determined by the resampling method using the FarmCPU P Threshold function. Each trait was exchanged 1000 times to break the relationship with the genotypes, and then the random association between all SNPs with the phenotype was estimated. The minimum $p$-value was recorded based on all SNPs for the 1000 repetitions, and then the $95 \%$ quantile of the entire minimum $p$-value was defined as the limit $p$-value [63]. The Bonferroni test [64] was also used as a threshold for the output in the Manhattan plot, to observe the dispersion of associations between SNP markers and the trait of interest.

\subsection{Candidate Gene Identification}

The significant SNPs were tested with a confidence interval of each SNP for size given by the size of the haplotype blocks in LD (i.e., using $\mathrm{r}^{2} \geq 0.2$ ), and the LD was estimated using squared allele-frequency correlation intrachromosomal pairs, through the Gaston package, available in R [65]. The LD decay curves for all chromosomes accessed from MDP was explained using the nonlinear model proposed by Hill and Weir [66], as described by Diniz et al. [48]. The common bean genome sequences were investigated using the BlastN analyses against the reference genome (Phaseolus vulgaris v 2.1; Schmutz et al. [51], using Jbrowse on Phytozome [67].

\section{Results}

\subsection{Evaluation of Fusarium Wilt Severity in Common Beans}

Common bean genotypes showed differential interaction when evaluated for resistance to Fop of both strains. At 21 DAI, genotypes that showed resistance against strains exhibited symptoms such as wilt, restricted necrosis of the first leaves, and a slight discoloration in the hypocotyl of the plant. However, susceptible genotypes showed wilt, necrosis, and severe discoloration in the hypocotyl, with generalized wilting throughout the plant, dwarfism, and consequently death.

The great variability of the MDP was confirmed by high significance $(p<0.01)$ of ANADEV for all evaluations, validating the use of both phenotypic evaluation for GWAS with respective adjusted means and genotypic data (Table S1. Broad-sense heritability $\left(\mathrm{h}^{2}\right)$ was from 0.48 to 0.63 , the lowest value being estimated for AUDPC of the IAC18001 strain $\left(h^{2}=0.48 \pm 0.08\right)$ and the highest value for DSR of the UFV01 strain $\left(h^{2}=0.63 \pm 0.09\right)$ (Table 1). 
Table 1. Broad-sense heritability, selective accuracy for resistance, overall mean of controls for two Fop strains evaluated for the Mesoamerican Diversity Panel (MDP) and likelihood radio test (LRT) of random effects of the DSR and AUDPC.

\begin{tabular}{|c|c|c|c|c|}
\hline \multirow{2}{*}{$\begin{array}{c}\text { Source of Variation } \\
\text { MDP }\end{array}$} & \multicolumn{2}{|c|}{ UFV01 Strain } & \multicolumn{2}{|c|}{ IAC 18001 Strain } \\
\hline & DSR & AUDPC & DSR & AUDPC \\
\hline Genotypes & $1220.14^{* *}$ & $3075.29 * *$ & $1024.71^{* *}$ & $2367.56^{* *}$ \\
\hline Broad-sense heritability & $0.63 \pm 0.09$ & $0.57 \pm 0.09$ & $0.55 \pm 0.08$ & $0.49 \pm 0.08$ \\
\hline Selective accuracy & 0.91 & 0.89 & 0.88 & 0.86 \\
\hline Mean resistant control ${ }^{1}$ & $1.67 \pm 0.20$ & $10.00 \pm 0.81$ & $1.66 \pm 0.11$ & $9.33 \pm 0.63$ \\
\hline Mean susceptible control ${ }^{2}$ & $7.67 \pm 0.56$ & $28.00 \pm 2.12$ & $7.23 \pm 0.86$ & $24.60 \pm 2.17$ \\
\hline Mean & $3.60 \pm 1.73$ & $17.40 \pm 7.48$ & $2.96 \pm 1.35$ & $13.60 \pm 3.78$ \\
\hline Pearson Correlation ${ }^{3}$ & \multicolumn{2}{|c|}{0.87} & \multicolumn{2}{|c|}{0.86} \\
\hline
\end{tabular}

${ }^{* *} p<0.01$ by the LRT and analysis of deviance; ${ }^{1}$ IAC Milênio cultivar, ${ }^{2}$ BRS Estilo cultivar. ${ }^{3}$ Pearson Correlation among DSR and AUDPC for each strain.

The UFV01 strain was more aggressive than IAC18001 in the MDP, with an increase of $17.7 \%$ in comparison to the overall mean of the DSR and of $21.8 \%$ in comparison to the overall mean of the AUDPC. The results showed that $46.82 \%$ (96) of the genotypes evaluated were categorized as resistant, $43.41 \%$ (89) as moderately resistant, and $9.77 \%$ (20) as susceptible to the UFV01 strain. In relation to the IAC18001 strain, 73\% (150) of the genotypes were classified as resistant, $23.90 \%$ (49) as moderately resistant, and $3.10 \%$ as susceptible (6). Of these, only $36 \%$ (75) of the genotypes were resistant to both strains, indicating the possibility of using them as sources of resistance to Fop in common bean breeding programs.

The IAC Milênio from the carioca commercial class may be considered an important source of Fop's resistance because it showed resistance to both strains (mean 1.67). It also retains high grain quality, resistance to seed coat darkening, and resistance to $C$. lindemuthianum $[68,69]$. Previous studies have shown that the cultivar also exhibits correlations between Fop's resistance and the rhizosphere microbiome composition, providing the first line of defense against root infections by soil-borne pathogens [70]. Another important source of resistance to Fop is the BRS FC402 cultivar, which is also a carioca cultivar with commercial grain quality and resistance to Fusarium wilt, and which showed a mean of 2.33 for both strains, corroborating the high resistance to Fop observed in previous studies [71].

The black seed coat cultivar IPR Uirapuru showed susceptibility to the UFV01 strain, with an average score in the evaluation to both strains of 5.5, corroborating with previous studies. It is a cultivar used as a standard for susceptibility to Fop [15]. However, the accessions LEG50600 and RAI 76 derived from CIAT (International Center for Tropical Agriculture, Cali, Colombia) showed good performance for both strains, with an average of 1.45 and 3.0, respectively. Both belong to the black bean commercial class and were previously characterized with root system traits, such as root dry matter, root surface area, and root volume, that showed positive and significant correlations with grain yield under drought [72].

Likewise, some accessions previously characterized as tolerant to water deficit had good performance in resistance to both strains of Fop, especially the genotypes BAT-477 [73], SEA-5 [74], SER-16, and IAC Imperador [75], with average scores of 1.33, 1.33, 2.65, and 2.0, respectively. BRS Estilo and A211 showed susceptibility to UFV01 through the root-dip inoculation method, with susceptibility levels like those previously reported $[19,55]$. This may be explained by the origin of UFV01, which was collected in Coimbra (MG, Brazil) and previously characterized as a highly virulent strain [20,55]. In contrast, IAC18001 was obtained in a naturally infested area at the Santa Elisa Farm of the Agronomic Institute (IAC, Campinas, SP, Brazil), where advanced evaluations and selection of elite bean lines and cultivars are routinely made in competition trials. 


\subsection{Association Mapping for Fusarium Wilt Resistance in the Mesoamerican Diversity Panel}

A total of 2001 SNPs were retained from the SNP calling, and these SNPs showed wide distribution over the 11 bean chromosomes (Figure 2). These markers were used for GWAS with the UFV01 and IAC18001 phenotypic data.

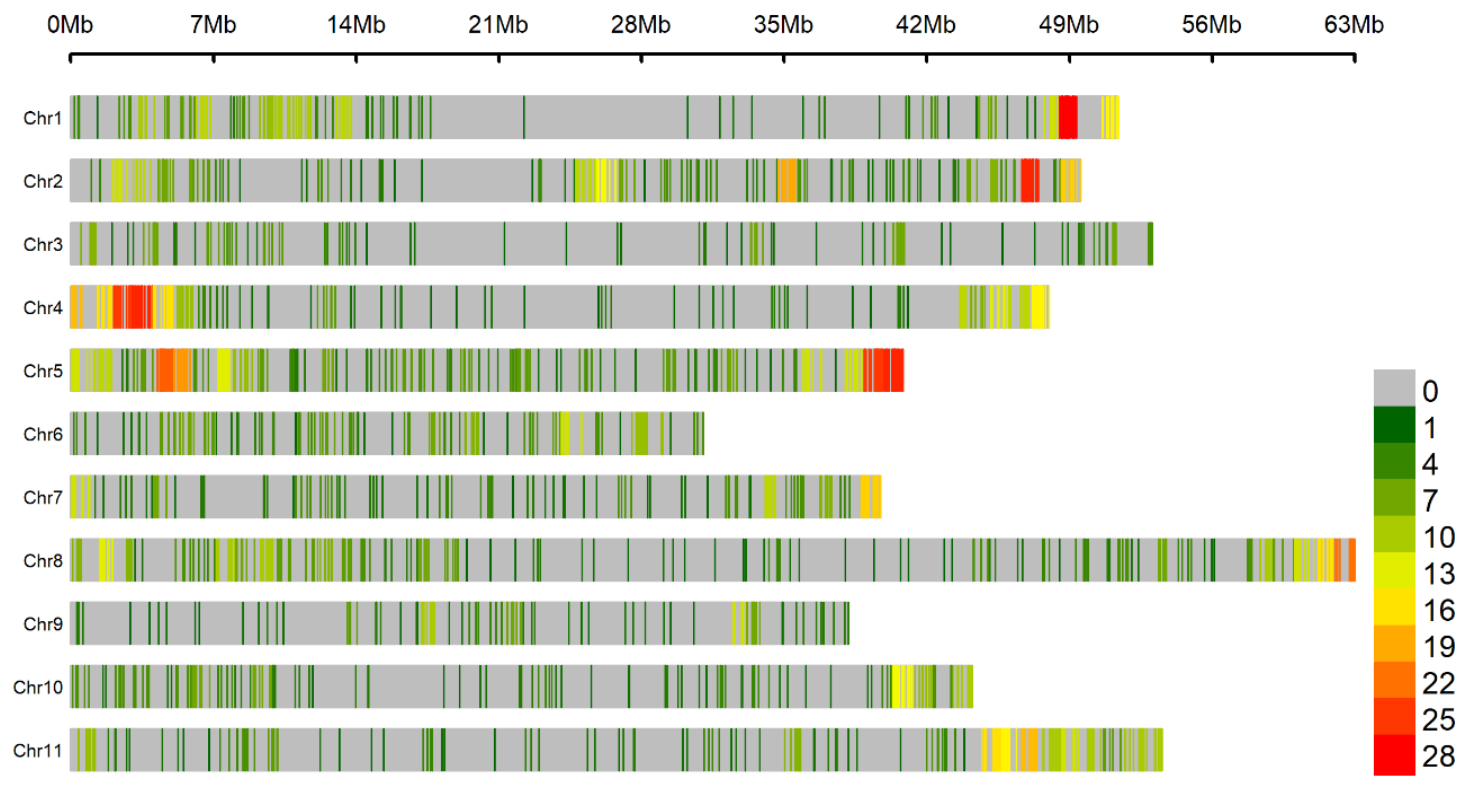

Figure 2. Density of 2001 SNPs in the MDP with 205 Mesoamerican genotypes. The different colors represent different density levels, and "Chr" refers to common bean chromosomes.

Considering the small size of the bean genome $(\sim 597 \mathrm{Mb})$ and the mean of LD decay of $\mathrm{r}^{2} \geq 0.2$ was approximately $0.6 \mathrm{Mb}$ for the Mesoamerican panel (Figure 3), the minimum number of SNPs required for good genome coverage and a satisfactory GWAS data was 1011, just over half of the number used in the present study (2001 SNPs).

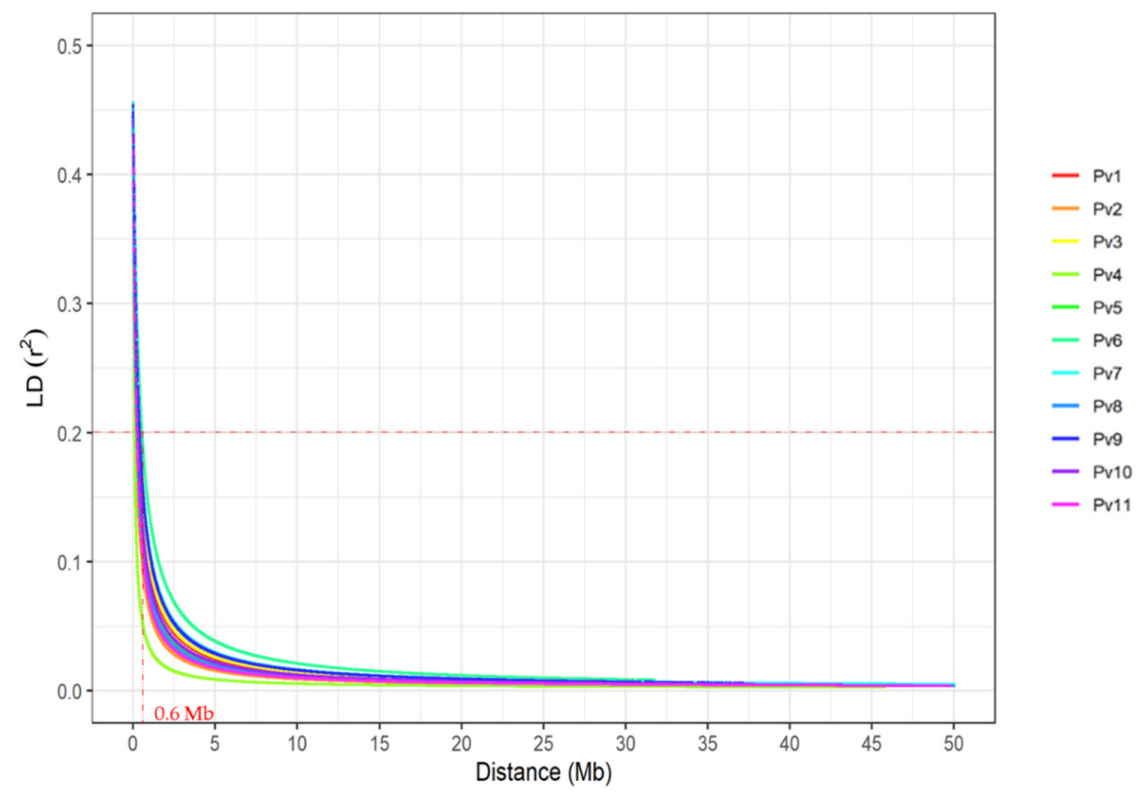

Figure 3. Linkage disequilibrium (LD) decay determined by the LD measurements $\left(\mathrm{r}^{2}\right)$ based on 2001 filtered common beans against the distance between SNPs $(\mathrm{Mb})$ for the 11 chromosomes $(\mathrm{Pv})$ adjusted according to the model proposed by Hill and Weir [66] controlled for relatedness and structure in the MDP with 205 Mesoamerican genotypes. 
In association analysis, the kinship matrix is necessary as a covariate for correction of possible false-positive type associations (type I error) (Figure 4A), and the structuring matrix is necessary only in the presence of strong genetic structuring, which was not observed by principal component analysis (PCA), with a small value of the total variance in three dimensions (Figure 4B).
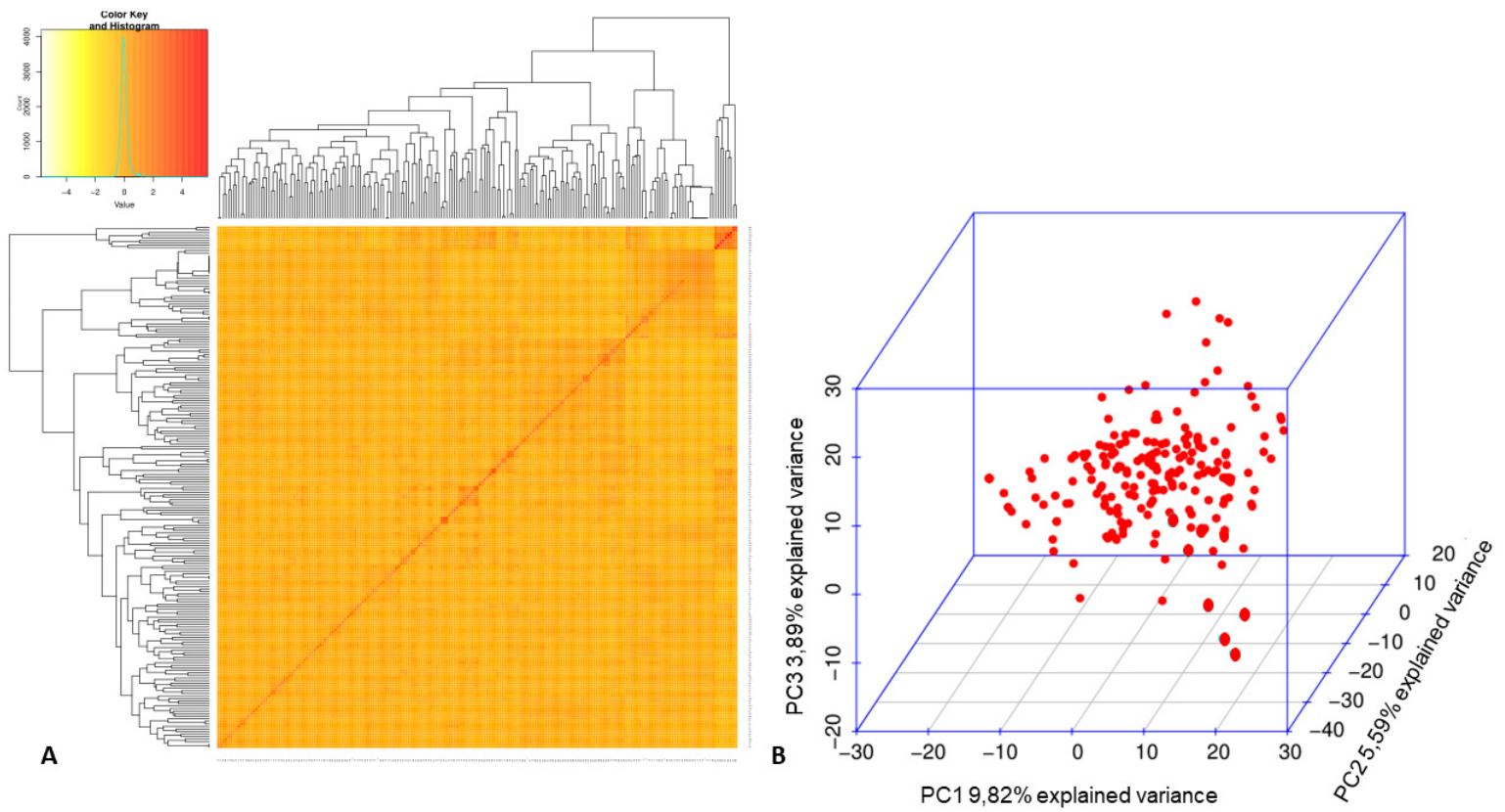

Figure 4. (A) Kinship plot of 205 common bean genotypes (MDP). (B) Principal component analysis calculated in the MDP with 205 genotypes and 2001 SNPs.

From the results obtained by PCA, the three principal components together explained only $19.3 \%$, showing a small amount of the total variance explained by these components. Furthermore, no formation of sub-structuring was observed for the MDP, which may be explained by the Mesoamerican origin of the genotypes. Moreover, according to the BIC (Bayesian Information Criterion, Schwarz [60], zero was the best number of components to use in the association model, making it clear that there was no need to use principal components to correct type I error (i.e., false positives), avoiding overfit of the model (Table S2).

Despite the lower number of markers due to MAF (Minor Allele Frequency), heterozygosity, and missing data filters that would allow a greater number of associated SNPs, the GWAS results showed 11 significant SNPs, for the UFV01 and IAC18001 strains. The significant marker-phenotype association for the DSR and AUDPC parameters based on the measurement of symptoms of chlorosis, plant wilt, and vascular discoloration of the hypocotyl. These SNPs were at different genomic regions on chromosomes Pv01, Pv03, Pv04, Pv05, Pv07, Pv10, and Pv11, as shown by the resampling method and the Bonferroni test $(\alpha=0.05)$. Of the eleven significant SNPs, six were within genes and five were close to candidate resistance genes, with distances ranging from 0.03 (Pv05) to $1.01 \mathrm{Mb}(\mathrm{Pv} 01)$ from these genes. In accordance with haplotype blocks with LD markers, confidence intervals were defined for the annotation of candidate genes to identify direct and indirect associations through markers that may be in LD with the significant marker and the trait. The LD plot per chromosome considering $\mathrm{r}^{2} \geq 0.2$, and formation of haplotypic blocks, is highlighted with a color key (Figure S1).

The negative effect $(-2.51)$ of the SNP associated with the UFV01 strain (SNP ss715645397 on Pv05) showed a decrease in the average values of Fop in the number of copies of the alternative allele " $\mathrm{T}$ " (Figure 5e). In contrast, the other significant SNPs had positive effects, with the highest value (2.08) for the SNP ss715648096 (Table 2), and 
the lowest value (0.37) for the SNP ss715646169 (Table 3). The marker ss715648096 (Pv11) was significant for the DSR and AUDPC parameters evaluated for the UFV01 strain and showed the phenotypic effect value of 0.73 for DSR and 2.08 for AUDPC; the two together explained $0.73 \%$ of the observed phenotypic variation (Table 2 ).
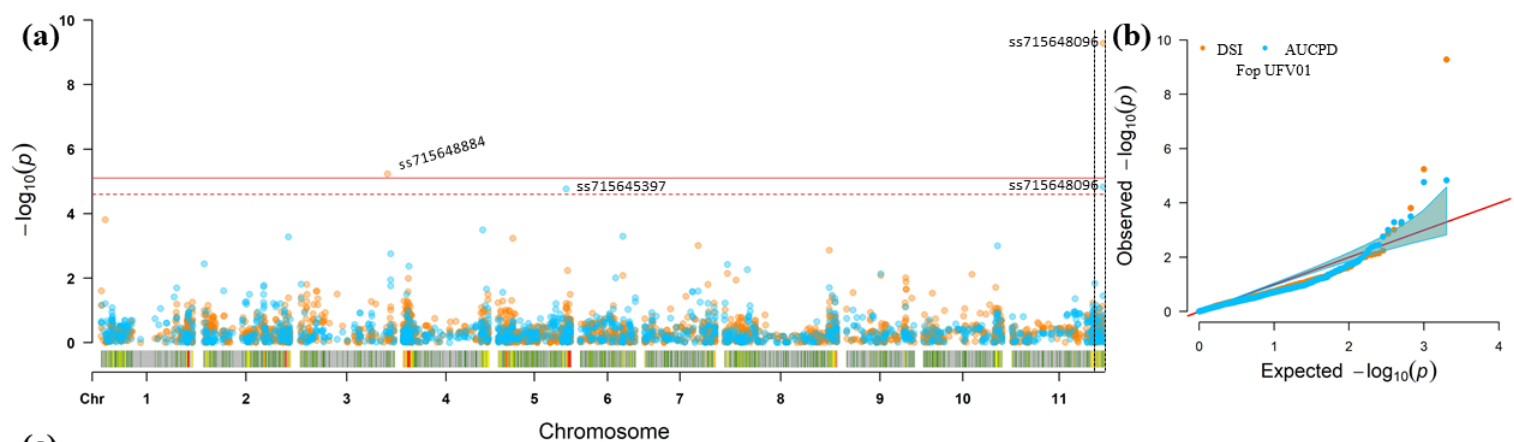

(c)
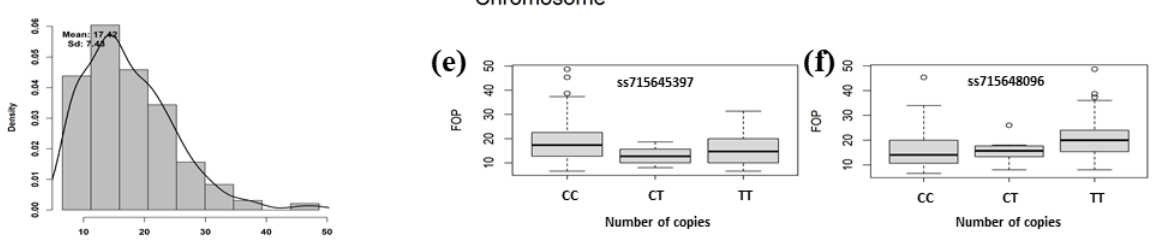

(d)

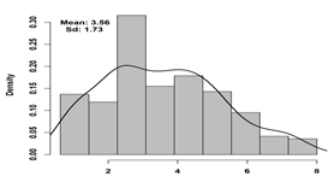

(g)

(h)

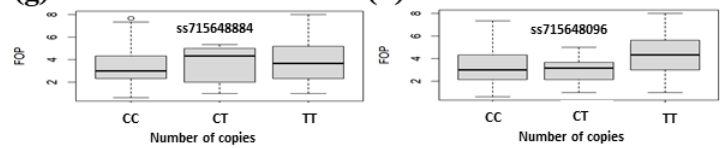

Figure 5. GWAS for Fop resistance in the MDP with 205 common bean genotypes with significant SNPs for the UFV01 strain using the DSR and AUDPC parameters and FarmCPU. (a) Manhattan plots and (b) Q-Q (Quantile-quantile) plots, with orange circles representing the $p$-values for DSR and blue circles the $p$-values for AUDPC. The dotted red line corresponds to the cut-offline obtained by the resampling method $-\log 10(p)=4.53 \times 10^{-5}$, and the upper red line refers to the cut-offline obtained by the Bonferroni method $(\alpha=0.05)$. (c,d) Histograms of the adjusted phenotypic means (BLUE) of AUDPC and DSR. (e-h) Boxplots of the relationship between the alleles and phenotype (Fop resistance) of each significant SNP for DSR and AUDPC.

Table 2. SNPs detected for the DSR and AUDPC for the UFV01 Fop strain for 205 common bean genotypes and 2001 SNPs: SNP's positions in mega base pairs $(\mathrm{Mb})$.

\begin{tabular}{ccccccccc}
\hline \multirow{2}{*}{ Trait } & Chr $^{\mathbf{1}}$ & $\begin{array}{c}\text { Position } \\
\text { v2.1 }\end{array}$ & SNP & $\boldsymbol{p}$-Value & MAF $^{\mathbf{2}}$ & Effect $^{\mathbf{4}}$ & Alleles $^{*} \mathbf{R}^{\mathbf{2} \% \mathbf{5}^{\mathbf{5}}}$ \\
\hline \multirow{2}{*}{ DSR } & Pv03 & $49,467,577$ & ss715648884 & $5.81 \times 10^{-6}$ & 0.21 & 0.63 & $\mathrm{C}^{\mathrm{e}} / \mathrm{T}^{\mathrm{f}}$ & 0.16 \\
& Pv11 & $51,500,684$ & ss715648096 & $5.27 \times 10^{-10}$ & 0.32 & 0.73 & $\mathrm{C}^{\mathrm{e}} / \mathrm{T}^{\mathrm{f}}$ & 0.64 \\
\hline \multirow{2}{*}{ AUDPC } & Pv05 & $38,267,303$ & ss715645397 & $1.73 \times 10^{-5}$ & 0.17 & -2.51 & $\mathrm{C}^{\mathrm{e}} / \mathrm{T}^{\mathrm{f}}$ & 0.09 \\
& Pv11 & $51,500,684$ & ss715648096 & $2.59 \times 10^{-5}$ & 0.32 & 2.08 & $\mathrm{C}^{\mathrm{e}} / \mathrm{T}^{\mathrm{f}}$ & 0.09 \\
\hline
\end{tabular}

${ }^{1}$ P. vulgaris chromosome; ${ }^{2}$ Position in base pairs (bp); ${ }^{3}$ Minor allele frequency; ${ }^{4}$ A positive effect of the allelic variant represents an increase in susceptibility, while a negative effect represents an increase in resistance to Fusarium wilt; ${ }^{5}$ Variance explained by each SNP-trait association (\%); ${ }^{\text {e }}$ Allelic reference; ${ }^{\mathrm{f}}$ Allelic variant.

For evaluation of resistance to the IAC18001 Fop strain, seven SNPs located on chromosomes Pv01, Pv03, Pv04, Pv05, Pv07, and Pv10 showed high significance (Figure 5). The marker ss715646169 (Pv05) was associated with DSR and AUDPC evaluated for the IAC18001 strain. The ss715646169 marker showed the phenotypic effect value with 0.37 for DSR and 1.15 for AUDPC; the two together explained $0.18 \%$ of the observed phenotypic variation (Table 3). 
Table 3. SNPs detected for the DSR and AUDPC for the IAC18001 Fop strain for 205 common bean genotypes and 2001 SNPs: SNP's positions in mega base pairs $(\mathrm{Mb})$.

\begin{tabular}{|c|c|c|c|c|c|c|c|c|}
\hline Trait & $\mathrm{Chr}^{1}$ & Position v2.1 ${ }^{2}$ & SNP & $p$-Value & MAF $^{3}$ & Effect $^{4}$ & Alleles & $R^{2 \%}{ }^{5}$ \\
\hline \multirow{3}{*}{ DSR } & Pv01 & $10,289,227$ & ss715649713 & $1.50 \times 10^{-5}$ & 0.18 & 0.45 & $A^{e} / C^{f}$ & 0.09 \\
\hline & Pv05 & $1,990,853$ & ss715646169 & $2.20 \times 10^{-5}$ & 0.22 & 0.37 & $\mathrm{~T}^{\mathrm{e}} / \mathrm{G}^{\mathrm{f}}$ & 0.09 \\
\hline & Pv10 & $41,966,104$ & ss715645508 & $3.02 \times 10^{-5}$ & 0.06 & 0.64 & $\mathrm{C}^{\mathrm{e}} / \mathrm{A}^{\mathrm{f}}$ & 0.09 \\
\hline \multirow{4}{*}{ AUDPC } & Pv03 & $50,473,206$ & ss715647339 & $3.36 \times 10^{-6}$ & 0.46 & 1.05 & $\mathrm{C}^{\mathrm{e}} / \mathrm{T}^{\mathrm{f}}$ & 0.16 \\
\hline & Pv04 & 155,465 & ss715648681 & $4.13 \times 10^{-6}$ & 0.50 & 0.98 & $\mathrm{~T}^{\mathrm{e}} / \mathrm{C}^{\mathrm{f}}$ & 0.09 \\
\hline & Pv05 & $1,990,853$ & ss715646169 & $2.42 \times 10^{-5}$ & 0.22 & 1.15 & $\mathrm{~T}^{\mathrm{e}} / \mathrm{G}^{\mathrm{f}}$ & 0.09 \\
\hline & Pv07 & $32,298,702$ & ss715647730 & $3.02 \times 10^{-5}$ & 0.19 & 1.21 & $\mathrm{C}^{\mathrm{e}} / \mathrm{T}^{\mathrm{f}}$ & 0.09 \\
\hline
\end{tabular}

${ }^{1}$ P. vulgaris chromosome; ${ }^{2}$ Position in base pairs (bp); ${ }^{3}$ Minor allele frequency; ${ }^{4}$ A positive effect of the allelic variant represents an increase in susceptibility, while a negative effect represents an increase in resistance to Fusarium wilt; ${ }^{5}$ Variance explained by each SNP-trait association (\%); ${ }^{\mathrm{e}}$ Allelic reference; ${ }^{\mathrm{f}}$ Allelic variant.

The effect values tended to increase the Fop (UFV01) means in accessions having two copies of the alternative allele (" $\mathrm{T}$ ") compared to the reference allele (" $\mathrm{C}$ ") and to the heterozygote pattern (“C/ $\mathrm{T}^{\prime \prime}$ ) (Figure $5 \mathrm{f}-\mathrm{h}$ ).

Regarding the allelic effect profile, a similar pattern was observed for SNPs associated with the IAC18001 strain, in which all SNPs with two copies of the alternative allele showed a positive effect, tending to increase Fop averages in accessions (Figure 6e-k).

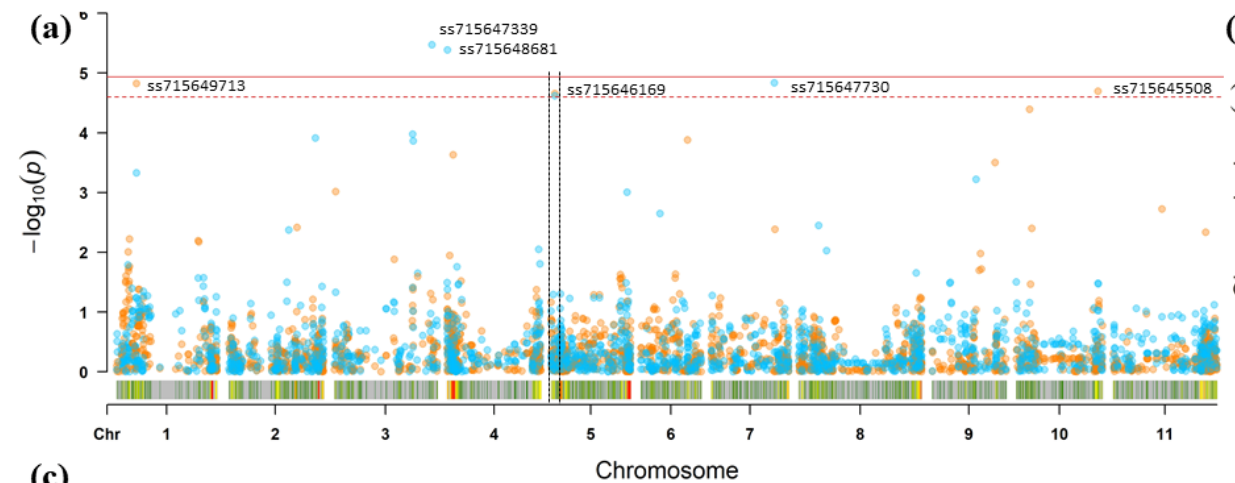

(c)

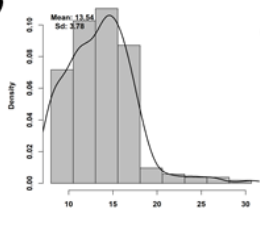

(e)

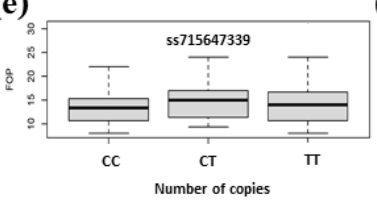

(f)

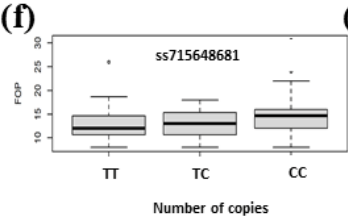

(g)

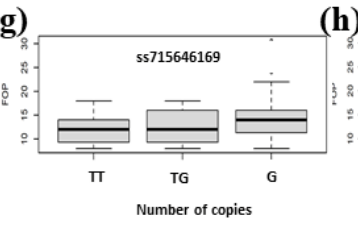

(d)

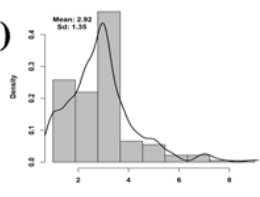

(i)

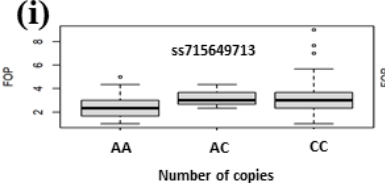

(j)

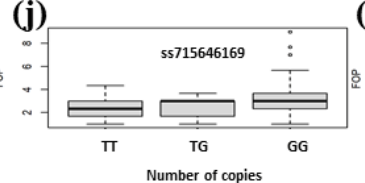

(h)
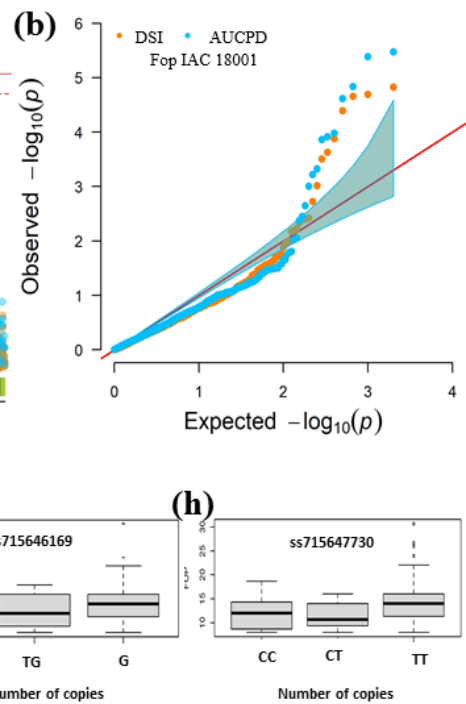

(k)

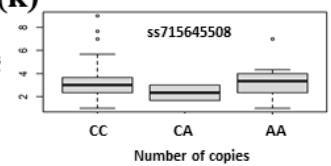

Figure 6. GWAS for Fop resistance in the MDP with 205 common bean genotypes with significant SNPs for the IAC18001 strain using the DSR and the AUDPC parameters and FarmCPU. (a) Manhattan plots and (b) Q-Q (Quantile-quantile) plots, with orange circles representing the $p$-values for DSR and blue circles the $p$-values for AUDPC. The dotted red line corresponds to the cut-offline obtained by the resampling method $-\log 10(p)=4.48 \times 10^{-5}$, and the upper red line refers to the cut-offline obtained by the Bonferroni method $(\alpha=0.05)$. (c,d) Histograms of adjusted phenotypic means (BLUE) of AUDPC and DSR. (e-k) Boxplots of the relationship between the allele and phenotype (Fop resistance) of each significant SNP for DSR and AUDPC. 


\subsection{Genomic Regions Associated with Fusarium Wilt Resistance}

Most of the significant SNPs showed different genomic regions when comparing the isolates, indicating that both strains characterized are from different races. Gene annotation identified a total of 78 genes associated with significant markers for the UFV01 strain (Table S3) and 329 genes for the IAC18001 strain (Table S4). In combined evaluation of the results obtained from the two strains, the SNPs located on Pv03 ss715647339 ( $p$-value $3.36 \times 10^{-6}$ IAC18001) and ss715648884 ( $p$-value $5.81 \times 10^{-6}$ UFV01) positioned at distance of $1.01 \mathrm{Mb}$ associated with Fusarium wilt reaction, with candidate genes for both strains in this genomic region (Table S5).

An important cluster of 20 genes related to the transcription of proteins related to resistance mechanisms (R) such as the LRR- and NB-ARC domain-containing disease resistance protein is located next to the marker ss715648096 positioned at $51.50 \mathrm{Mb}$ on Pv11. The cluster of 20 putative candidate genes was observed for the UFV01 strain considering DSR and AUDPC parameters at $0.03 \mathrm{Mb}$ to $0.39 \mathrm{Mb}$ from the significant marker in association analyses (Table 4).

Table 4. Annotation of candidate genes with a confidence interval $(0.464 \mathrm{Mb})$ of each significant SNP ss715648096 associated with the Fusarium wilt strain UFV01 for DSR ( $p$-value $5.27 \times 10^{-10)}$ and AUDPC $\left(p\right.$-value $\left.2.59 \times 10^{-5}\right)$ for 205 common bean genotypes and 2001 SNPs: SNP's positions in mega base pairs $(\mathrm{Mb})$.

\begin{tabular}{ccc}
\hline Gene & Distance & Description \\
\hline Phvul.011G200300 & 0.035 & NB-ARC domain-containing disease resistance protein \\
Phvul.011G200800 & 0.069 & LRR/NB-ARC domain-containing disease resistance protein \\
Phvul.011G200820 & 0.103 & NB-ARC domain-containing disease resistance protein \\
Phvul.011G200840 & 0.109 & LRR and NB-ARC domain-containing disease resistance protein \\
Phvul.011G200860 & 0.111 & NB-ARC domain-containing disease resistance protein \\
Phvul.011G200880 & 0.122 & LRR and NB-ARC domain-containing disease resistance protein \\
Phvul.011G200900 & 0.141 & NB-ARC domain-containing disease resistance protein \\
Phvul.011G201000 & 0.151 & LRR and NB-ARC domain-containing disease resistance protein \\
Phvul.011G201101 & 0.159 & NB-ARC domain-containing disease resistance protein \\
Phvul.011G202000 & 0.248 & NB-ARC domain-containing disease resistance protein \\
Phvul.011G202200 & 0.264 & LRR and NB-ARC domain-containing disease resistance protein \\
Phvul.011G202366 & 0.295 & NB-ARC domain-containing disease resistance protein \\
Phvul.011G202432 & 0.297 & NB-ARC domain-containing disease resistance protein \\
Phvul.011G202601 & 0.341 & LRR and NB-ARC domain-containing disease resistance protein \\
Phvul.011G202750 & 0.343 & LRR and NB-ARC domain-containing disease resistance protein \\
Phvul.011G202800 & 0.344 & Disease resistance protein (TIR-NBS-LRR class) family \\
Phvul.011G202900 & 0.347 & LRR and NB-ARC domain-containing disease resistance protein \\
Phvul.011G202966 & 0.365 & NB-ARC domain-containing disease resistance protein \\
Phvul.011G203032 & 0.388 & LRR and NB-ARC domain-containing disease resistance protein \\
Phvul.011G203100 & 0.393 & LRR and NB-ARC domain-containing disease resistance protein \\
\hline
\end{tabular}

${ }^{1}$ Distance among de significant SNP and candidate gene $(\mathrm{Mb})$.

The marker ss715646169 positioned at $1.99 \mathrm{Mb}$ on Pv05 was significant for the IAC18001 strain (DSR and AUDPC parameters). This significant marker was positioned at $0.00 \mathrm{Mb}$ and 0.56 from the candidate genes. The putative genes found were involved in disease resistance and related to important factors of transcription involved in biological signaling functions in drought tolerance and vascular diseases in plants (Table 5).

The significant markers ss715647339 ( $p$-value $3.36 \times 10^{-6}$ IAC18001) and ss715648884 ( $p$-value $5.81 \times 10^{-6}$ UFV01) were associated with Fop for both strains at $0.27 \mathrm{Mb}$ and 0.51 from the candidate genes (Table 6). Among them, we found genes involved in root development mechanisms, in the transcription of disease-resistant proteins, and transcription factors involved in the important biological functions of signaling of drought tolerance and precursors of enzymes associated with flavonoid biosynthesis. 
Table 5. Annotation of candidate genes with a confidence interval $(0.694 \mathrm{Mb})$ of each significant SNP ss715646169 associated with the Fusarium wilt (Fop) strain IAC18001 for DSR ( $p$-value $2.20 \times 10^{-5}$ ) and AUDPC ( $p$-value $2.42 \times 10^{-5}$ ) for 205 common bean genotypes and 2001 SNPs: SNP's positions in mega base pairs $(\mathrm{Mb})$.

\begin{tabular}{ccc}
\hline Gene & Distance ${ }^{1}$ & Description \\
\hline Phvul.005G016200 & 0.561 & Zinc ion binding \\
Phvul.005G016300 & 0.556 & Late embryogenesis abundant protein, group 1 protein \\
Phvul.005G016500 & 0.541 & Disease resistance protein (TIR-NBS-LRR class), putative \\
Phvul.005G017000 & 0.510 & Protein kinase superfamily protein \\
Phvul.005G018300 & Proline-rich family protein \\
Phvul.005G020000 & 0.415 & Zinc finger (CCCH-type/C3HC4-type RING finger) protein \\
Phvul.005G020100 & 0.261 & Zinc finger (CCCH-type/C3HC4-type RING finger) protein \\
Phvul.005G020600 & 0.251 & Ubiquitin carboxyl-terminal hydrolase family protein \\
Phvul.005G021300 & 0.247 & Putative methyltransferase family protein \\
Phvul.005G022000 & 0.197 & Microtubule-associated proteins \\
Phvul.005G022100 & 0.129 & CCCH-type zinc finger protein with ARM repeat domain \\
& 0.018 & Cellulose synthase family protein
\end{tabular}

${ }^{1}$ Distance among de significant SNP and candidate gene $(\mathrm{Mb})$.

Table 6. Annotation of candidate genes with a confidence interval $(1.001 \mathrm{Mb})$ of significant SNPs ss715647339 ( $p$-value $3.36 \times 10^{-6}$ IAC18001) and ss715648884 ( $p$-value $5.81 \times 10^{-6}$ UFV01) associated with Fusarium wilt for 205 common bean genotypes and 2001 SNPs: SNP positions in mega base pairs $(\mathrm{Mb})$.

\begin{tabular}{ccc}
\hline Gene & Distance $^{1}$ & Description \\
\hline Phvul.003G258100 & 0.277 & Lateral root primordium (LRP) protein-related \\
Phvul.003G258400 & 0.348 & Cytochrome P450 superfamily protein \\
Phvul.003G258700 & 0.381 & Leucine-rich repeat (LRR) family protein \\
Phvul.003G258800 & 0.386 & Leucine-rich receptor-like protein kinase family protein \\
Phvul.003G259700 & 0.447 & Serine carboxypeptidase S28 family protein \\
Phvul.003G260000 & 0.465 & Serine carboxypeptidase S28 family protein \\
Phvul.003G260100 & 0.481 & B-box type zinc finger family protein \\
Phvul.003G260200 & 0.495 & ATP binding microtubule motor family protein \\
Phvul.003G260300 & 0.514 & Leucine-rich receptor-like protein kinase family protein \\
\hline${ }^{1}$ Distance among de significant SNP and candidate gene $(\mathrm{Mb})$.
\end{tabular}

\section{Discussion}

The success of association mapping in identifying markers effectively associated with the trait depends on how well the population structure is corrected in the association model and on the existing levels of LD [76]. In a bean population, using a kinship matrix containing the population structure has been widely used in genome-wide association studies, successfully correcting the genetic relatedness between individuals using linear mixed models $[48,77]$. For association mapping in common bean, gene pools should be considered separately, because LD decays more rapidly within the Andean gene pool and is stronger within the Mesoamerican gene pool [5,78].

Regarding the Mesoamerican panel, the parameters observed in the current study agreed with those presented by [37], who evaluated a Mesoamerican carioca (cream-colored seed coat with brown stripes) panel, which is, in fact, part of the MDP used. The BIC test was performed for the first five components, and no PCs were required for any of the traits. The formation of haplotypic blocks within the LD markers ranging from $0.03 \mathrm{Mb}$ (Pv05) to $1.01 \mathrm{Mb}$ (Pv01) indicated that the markers evaluated represent the possible constituent haplotypes in the Mesoamerican panel [79].

Fop is genetically variable and often found in common bean growing in different countries and regions; up to now, seven pathogenic races related to geographical regions are cited in the literature $[20,80,81]$, and new races like UFV01 and IAC18001 occur, supporting Fop pathogenic evolution [82]. However, mutations and recombination between 
avirulence genes (avr) in sexually reproducing pathogens are postulated as the mechanisms responsible for variation in races [83].

Resistance genes can be overcome by new or more virulent races; hence, broadspectrum, durable resistance is needed [84]. In the current study, only 75 accessions $(36.58 \%)$ showed resistance to both strains of Fop, demonstrating the difficulty of obtaining genotypes with resistance to different races of the fungus. Sala et al. (2006) evaluated 104 bean genotypes, of which 33\% were resistant to the Fop 1, 2, 3, and 4 races, indicating the difficulty of finding cultivars with multiple resistance to the pathogen. Leitão et al. [25] evaluated a panel containing predominantly Andean accessions and the Fop race 06 and observed only 14 accessions $(9.27 \%$ ) with resistance to the fungus, with heritability values from $40.8 \%$ to $71.5 \%$ considering the DSR and AUDPC parameters (49\% and $63 \%$ ).

Important SNPs associated with QTL (Quantitative Trait loci) in the current study were associated with Fop resistance (represented by the parameters DSR and AUDPC) for the two strains tested (UFV01 and IAC18001). The differences reflect the varied resistance spectra exhibited by these accessions. Despite the experiments with both strains being conducted in few experiments under controlled conditions, some of the QTL identified in this study are confirmed by the literature, evidencing the robustness of results. However, the successful establishment of disease by the Fop pathogen demands a response in the plant defense system, and the entire molecular mechanism of pathogenesis remains to be elucidated to improve selective accuracy with additional experiments involving high-throughput phenotyping [85,86].

In bean, Fop penetrates the epidermis of the plant roots, invades the cortex, and colonizes the vascular tissue of the host plant, causing obstruction and wilting $[14,15]$. Pathogens other than Fusarium spp. can cause wilting in legumes; pathogens such as Rhizoctonia spp., Verticillium spp., and Aphanomyces euteiches [87]. Gupta et al. [88] confirmed that genes associated with the secondary cell wall are involved in the combined response of the plant to infection from wilt pathogens and to drought in Arabidopsis thaliana.

Furthermore, since we are likely dealing with polygenic inheritance with small additive genetic effects, increasing the sample size, thus maximizing the phenotypic diversity among the MDP, would enhance the power to recover meaningful associations $[23,25]$. Most of the SNPs associated by GWAS revealed that the genomic regions linked to Fop traits were located inside or near the candidate genes on Pv01, Pv03, Pv04, Pv05, Pv07, Pv10, and Pv11 (Tables 2 and 3).

The Pv01 chromosome also showed a significant SNP, ss715649713, associated with DSR for the IAC18001 strain at the $1.01 \mathrm{Mb}$ LD haplotype block, positioned within the Phvul.001G074800 (Appr-1-p processing enzyme family protein) gene. Appr-1-pase is an important and ubiquitous cellular processing [89]. Ubiquitination is a known mechanism in the regulation of plant defense against pathogens [90]. Recent evidence shows that ubiquitination plays a critical role in regulating plant responses to abiotic stresses and plant tolerance of adverse environmental conditions [91]. The ubiquitination mechanism may also be associated with actions on specific components for stress signaling [92].

On Pv03, two significant SNPs associated with the Fop reaction were found, the ss715647339 (IAC18001) and ss715648884 (UFV01) positioned at a distance of $1.01 \mathrm{Mb}$, and showed potential candidate genes involved in root development mechanisms (Phvul.003G 258100) and in presumed disease-resistance proteins (Phvul.003G258700, Phvul.003G258800, and Phvul.003G260300). The Phvul.003G258400 gene is associated with the putative Cytochrome P450 superfamily protein also in this region family members can act in the control of abscisic acid (ABA) production that are involved in critical processes in plant growth and development. They can also act in biotic and abiotic stress responses [93,94] and the formation of secondary metabolites, such as terpenoids, flavonoids, steroids, alkaloids, phenylpropanoids, glucosinolate, and cyanogenic glycoside all of which are typically made as part of host defense [95].

The SNP ss715648681 identified on Pv04 associated with AUDPC for the IAC18001 strain is positioned within the Phvul.004G001900 gene (MATE efflux family protein). In 
plants, MATE transporters have been directly or indirectly implicated in mechanisms of disease resistance [96], in the transport of diverse types of secondary metabolites, such as alkaloids [97], flavonoids [98,99], anthocyanidins [100], and hormones, such as salicylic acid (SA) and ABA, and in drought tolerance [101]. Mandal et al. [102] demonstrated that the induced resistance observed in tomato against Fusarium oxysporum f. sp. lycopersici (Fol) might be a case of salicylic acid-dependent systemic acquired resistance.

Another significant SNP, ss715645397, was found in Pv05 associated with AUDPC for UFV01 at $0.004 \mathrm{Mb}$ from the Phvul.005G152600 gene (ARM repeat superfamily protein). The Armadillo (ARM) domain has motifs with the structure of repeat proteins, such as Leucine-rich repeats (LRR), that have been extensively studied in plants, suggesting a critical role of these repeating peptides in plant cell physiology, plant stress, and plant development [103]. In this region close to the marker, Nakedde et al. [46] identified a QTL mapped in a recombinant inbred line (RIL) population that accounted for $9.20 \%$ to $10.06 \%$ of phenotypic variation associated with Fusarium Root Rot (FRR) and root architecture traits. This QTL was located at $39.22 \mathrm{Mb}$ in a $0.31 \mathrm{Mb}$ interval on Pv05.

Another candidate gene associated with the ss715646169 marker positioned at $1.99 \mathrm{Mb}$ on Pv05 (between $0.0 \mathrm{Mb}$ and $0.56 \mathrm{Mb}$ ) for DSR and AUDPC of the IAC18001 strain. This marker was positioned within the Phvul.005G022100 gene (Cellulose synthase family protein). The cellulose synthase (CesA) superfamily genes are among the most important agents involved in the biosynthesis of plant cell walls, which are mainly composed of biopolymers such as celluloses, hemicelluloses, pectins, and lignins [104]. Among the several defense mechanisms in the plant-pathogen resistance interaction, structural changes must be highlighted. These structural changes lead to strengthening of the plant cell wall by the deposition of callose, followed by lignification, a phenomenon that can be determinant in a resistance or susceptibility reaction in interaction with Fusarium oxysporum, with the possibility of quantitative differences in response [105].

Our results showed a group of candidate gene associated with the ss715646169 marker are the genes related to the zinc finger domain (Phvul.005G016200; Phvul.005G019900; Phvul.005G020000 and Phvul.005G022000). Zinc finger proteins play a crucial role in many metabolic pathways, as well as in stress response and defense in plant-pathogen interactions to the defense of plants, and may be associated with a JA-dependent defense pathway [106,107]. The SNP ss715647730 identified on Pv07 and associated with AUDPC for IAC18001 was positioned at $0.01 \mathrm{Mb}$ from the Phvul.007G199600 gene (droughtresponsive family protein). Although drought-responsive proteins exhibit various patterns depending on plant species, genotypes, and stress intensity, proteomic analyses show that dominant changes occurred in sensing and signal transduction, reactive oxygen species scavenging, osmotic regulation, gene expression, protein synthesis/turnover, cell structure modulation, and carbohydrate and energy metabolism [108].

Leitão et al. [25] performed association mapping for Fop race 06 using a panel of 133 common bean accessions from Portugal and observed significant associations detected for DSR and AUDPC on the Pv04, Pv05, Pv07, and Pv08 chromosomes. They noted that the DART03480 marker on Pv04 was at a small distance of approximately $0.1 \mathrm{Mb}$ from the ss715648681 marker, which was also detected in our study.

The Pv10 chromosome showed a significant SNP, ss715645508, positioned at a distance of $0.001 \mathrm{Mb}$ from the Phvul.010G137000 gene (SNARE-like superfamily protein). This gene may be considered a novel determinant of salinity/drought tolerance and a potential candidate to increase salinity and drought tolerance in crop plants [109]. Erfatpour et al. [110] identified a QTL in this same genomic region between $39.97 \mathrm{Mb}$ and $40.29 \mathrm{Mb}$, with forty candidate genes associated with non-darkening (ND) in seed coat color at $1.6 \mathrm{Mb}$ from the significant marker in our study.

Linkage mapping reported genomic regions associated with Fop resistance to race 04 [23]. The authors identified significant markers positioned on Pv03, Pv10, and Pv11, and a QTL of greater effect that explained $63.5 \%$ of the phenotypic variance on Pv10. A SCAR marker (U20.750) linked to this QTL was developed, with evaluation in Andean 
and Mesoamerican germplasm, and the marker had high accuracy in Mesoamerican accessions [111].

Gene annotation allowed the identification of candidate genes associated with putative effects in disease-resistance mechanisms (R), such as a cluster of 20 candidate genes annotated as "leucine-rich repeat-containing protein" (LRR), with distances from $0.03 \mathrm{Mb}$ from the Phvul.011G200300 gene up to $0.39 \mathrm{Mb}$ from the Phvul.011G203100 gene positioned close to the ss715648096 marker on Pv11 associated with DSR and AUDPC for UFV01 (Table 4). The region of $51.50 \mathrm{Mb}$ associated with the significant ss715648096 marker on Pv11 corroborates previous studies, and the region being associated with other important fungal diseases of common bean, such as anthracnose, by the association of marker S11_51790295 to race 73 of Colletotrichum lindemuthianum (the anthracnose pathogen), positioned at a distance of approximately $0.20 \mathrm{Mb}$ [112]. The identification of LRR receptor-like protein kinases $(\mathrm{PK})$ and their role in adaptive selection supports prior literature indicating a co-evolution of common bean and the anthracnose fungus $[44,113]$.

The GWAS of the Mesoamerican panel also revealed the S11_50585184 marker at $0.91 \mathrm{Mb}$ from the ss715648096 marker associated with Fop that is related to the Phvul.011G 192400 (NBS-LRR with typical NB-ARC domain) gene associated with Rhizoctonia solani resistance on Pv11 [36]. The response to different soil diseases may be because the NB-ARC domain contains a functional ATPase region that regulates the resistance, and this domain interacts with the nucleotide-binding domain in order to exchange the nucleotides that are associated with activating ATPase change, which, in turn, reshapes to NB-ARC ATPase and alters resistance specificity and the possibility that the LRR interacts with similar elicitors from both pathogens [114,115].

Hoyos-Villegas et al. [116] used the GWAS procedure for wilting score associated with drought-tolerant genotypes and reported one significant association at the SNP ss715639678, which is located at the end of Pv11, in a region that was found to be in high LD, with 1131 genes. In addition, gene ontology enrichment analysis revealed 19 biological processes and 30 molecular functions that were significantly associated. Myers et al. [117], using GWAS for finding markers associated with total phenolic content (TPC), identified 11 QTNs linked with TPC, especially the SNP ss715650328 at $52.96 \mathrm{Mb}$ on Pv11. Various biological functions may be related, including the production of compounds such as phenolic acids, flavonoids, and proanthocyanidins, which are the main polyphenols associated with plant defense and postharvest darkening in common bean $[118,119]$.

The physical barriers that act at different levels in defending plants inhibit the penetration and colonization of plant tissues by the pathogen, associated with biochemical reactions in the host cells that produce toxic substances and/or create adverse conditions for growth of the pathogen inside the plant. Therefore, substances produced in the host cells, before or after infection, contribute significantly to resistance [120].

Some signaling components, such as phytohormones, combined with functional gene transcription factors and their regulators, are involved in responses to combined abiotic and biotic stresses in plants, factors that can be modulated according to environmental conditions [121]. The effect of water can modulate the response of the plant to pathogens, in which several pathogens translocate virulence proteins (effectors) into host cells to target different components of the plant [122].

Chen et al. [27], using whole transcriptome and metabolome, showed bean-Fop pathosystem includes different and effective defense pathways comprising of a complex resistance network of structural, signaling, and chemical responses. The authors demonstrated the validation of differentially expressed genes located in Pv03, Pv04, Pv07, Pv08 and Pv11 by qRT-PC showing strong roles in signaling routes such as salicylic acid (SA), jasmonate, and ethylene. Fop also induced the flavonoid biosynthesis pathway which was the most significantly enriched one in response to Fop's infection.

Xue et al. [123] using the cDNA amplified fragment length polymorphisms (cDNAAFLPs), found five transcript-derived fragments involved in the mechanism of plant hormone regulation. These five genes belonged to the jasmonate, auxin, Abscisic acid 
(ABA), and SA-dependent pathways can be implicated to play a role in the plant's defense responses.

After exposure to the pathogen, the plant starts a signaling network mediated by protein kinases, such as mitogen-activated protein kinases (MAPK) and begins a process of recognition of pathogen-associated molecular patterns (PAMPs) through their PAMP-recognition receptors (PRRs), known as pattern-triggered immunity (PTI) and pathogen effector-triggered immunity (ETI), two important mechanisms for averting disease attacks [124].

\section{Conclusions}

In our study, the SNPs and putative candidate genes associated with Fop resistance may help to broaden understanding of the pathways involved in bean response to Fop infection. Significant markers related to Fop resistance showed common response mechanisms similar to other bean diseases, in association with root architecture traits, which is indeed the entrance of Fop infection. These genes thus affect the drought-tolerance response of the plants and the production of phenolic compounds, indicating a complex gene network with pleiotropic effects in common beans related to this disease. However, we recommend future studies involving field conditions using high-throughput phenotyping and different approaches (i.e., linkage mapping, transcriptome and metabolome) to validate the results obtained with Mesoamerican derived beans. The putative candidate genes associated with the SNPs in the current study increase the number of functional markers available to facilitate possible application to breeding by genomic selection for Fop resistance in common bean.

Supplementary Materials: The following are available online at https:/ /www.mdpi.com/article/10 .3390 /genes12050765/s1, Figure S1: LD plot considering $\mathrm{r}^{2} \geq 0.2$ for LD haplotype on chromosomes Pv01, Pv03, Pv04, Pv05, Pv07, Pv10, and Pv11, Table S1: Summary of phenotypic and genotypic data for bean lines within the Mesoamerican Diversity Panel (MDP), Table S2: Bayesian Information Criterion (BIC) test; larger is better, according to Schwarz, (1978), Table S3: Gene annotation for the significant SNPs from GWAS in MDP genotypes for the UFV01 strain (https:/ / phytozome.jgi.doe. gov/pz/portal.html, accessed on 14 May 2021. Table S4: Gene annotation for the significant SNPs from GWAS in MDP genotypes for the Fop IAC18001 strain (https:/ / phytozome.jgi.doe.gov/pz/ portal.html, accessed on 14 May 2021. Table S5: Gene annotation for the common significant SNPs from GWAS in MDP genotypes for Fop UFV01 and IAC18001 strains (https:/ / phytozome.jgi.doe. gov/pz/portal.html, accessed on 14 May 2021.

Author Contributions: L.L.B.-R., A.F.C., and J.F.d.C.P., designed the study and L.L.B.-R. was responsible for the project funding. J.F.d.C.P. and C.P.d.A. conceived the structure of the manuscript, and J.F.d.C.P. wrote the initial manuscript. J.F.d.C.P., C.J.B., and C.P.d.A. conducted the experiments. J.F.d.C.P., C.J.B., C.P.d.A., and R.F.-N., performed the data analysis. C.J.B., supported the phenotyping curation and R.F.-N. the accuracy of the analysis. L.L.B.-R., A.F.C., Q.S., and S.A.M.C. supported the data curation and reviewed the manuscript. All authors have read and agreed to the published version of the manuscript.

Funding: This research was funded by the Fundação de Amparo à Pesquisa do Estado de São Paulo (FAPESP), grant number Proc. 2017/24711-4 and scholarships 2017/01753-3, 2018/15526-1, and 2019/19670-2, and Coordenação de Aperfeiçoamento de Pessoal de Nível Superior through scholarship grants.

Institutional Review Board Statement: Not applicable.

Informed Consent Statement: Not applicable.

Data Availability Statement: Not applicable.

Acknowledgments: Our thanks to Renata Oliveira Batista for provided the Fop UFV01 strain.

Conflicts of Interest: The authors declare no conflict of interest. 


\section{References}

1. Bitocchi, E.; Bellucci, E.; Giardini, A.; Rau, D.; Rodriguez, M.; Biagetti, E.; Santilocchi, R.; Spagnoletti Zeuli, P.; Gioia, T.; Logozzo, G.; et al. Molecular analysis of the parallel domestication of the common bean (Phaseolus vulgaris) in Mesoamerica and the Andes. New Phytol. 2013, 197, 300-313. [CrossRef]

2. Mamidi, S.; Rossi, M.; Annam, D.; Moghaddam, S.; Lee, R.; Papa, R.; McClean, P. Investigation of the domestication of common bean (Phaseolus vulgaris) using multilocus sequence data. Funct. Plant Biol. 2011, 38, 953-967. [CrossRef]

3. De Ron, A.M.; Santalla, M. Phaseolus vulgaris (Beans). In Brenner's Encyclopedia of Genetics, 2nd ed.; Elsevier Inc.: Amsterdam, The Netherlands, 2013; pp. 290-292, ISBN 9780080961569.

4. Singh, S.P.; Gepts, P.; Debouck, D.G. Races of common bean (Phaseolus vulgaris, Fabaceae). Econ. Bot. 1991, 45, 379-396. [CrossRef]

5. Burle, M.L.; Fonseca, J.R.; Kami, J.A.; Gepts, P. Microsatellite diversity and genetic structure among common bean (Phaseolus vulgaris L.) landraces in Brazil, a secondary center of diversity. Theor. Appl. Genet. 2010, 121, 801-813. [CrossRef]

6. Blair, M.W.; Izquierdo, P.; Astudillo, C.; Grusak, M.A. A legume biofortification quandary: Variability and genetic control of seed coat micronutrient accumulation in common beans. Front. Plant. Sci. 2013, 4. [CrossRef] [PubMed]

7. Chacón, S.M.I.; Pickersgill, B.; Debouck, D.G. Domestication patterns in common bean (Phaseolus vulgaris L.) and the origin of the Mesoamerican and Andean cultivated races. Theor. Appl. Genet. 2005, 110, 432-444. [CrossRef]

8. Gepts, P.; Osborn, T.C.; Rashka, K.; Bliss, F.A. Phaseolin-protein Variability in Wild Forms and Landraces of the Common Bean (Phaseolus vulgaris): Evidence for Multiple Centers of Domestication. Econ. Bot. 1986, 40, 451-468. [CrossRef]

9. Gepts, P.; Bliss, F.A. Dissemination pathways of common bean (Phaseolus vulgaris, Fabaceae) deduced from phaseolin electrophoretic variability. II. Europe and Africa. Econ. Bot. 1988, 42, 86-104. [CrossRef]

10. FAO. FAOSTAT Food and Agriculture Organization of the United Nations (FAO); FAO Statistics Division: Rome, Italy, 2019.

11. Companhia Nacional de Abastecimento (CONAB). Acompanhamento da safra brasileira de grãos: Safra 2018/19-Décimo segundo levantamento. Cia. Nac. de Abast. 2019, 6, 1-126.

12. Panth, M.; Hassler, S.C.; Baysal-Gurel, F. Methods for management of soilborne diseases in crop production. Agriculture 2020, 10, 16. [CrossRef]

13. De Toledo-Souza, E.D.; da Silveira, P.M.; Café-Filho, A.C.; Lobo Junior, M. Fusarium wilt incidence and common bean yield according to the preceding crop and the soil tillage system. Pesquisa Agropecuária Brasileira 2012, 47, 1031-1037. [CrossRef]

14. Pereira, A.C.; Cruz, M.F.A.; Paula Júnior, T.J.; Rodrigues, F.A.; Carneiro, J.E.S.; Vieira, R.F.; Carneiro, P.C.S. Infection process of Fusarium oxysporum f. sp. phaseoli on resistant, intermediate and susceptible bean cultivars. Trop. Plant Pathol. 2013, 38, 323-328. [CrossRef]

15. Garcés-Fiallos, F.R.; de Borba, M.C.; Schmidt, É.C.; Bouzon, Z.L.; Stadnik, M.J. Delayed upward colonization of xylem vessels is associated with resistance of common bean to Fusarium oxysporum f. sp. phaseoli. Eur. J. Plant Pathol. 2017, 149, 477-489. [CrossRef]

16. Niño-Sánchez, J.; Tello, V.; Casado-del Castillo, V.; Thon, M.R.; Benito, E.P.; Díaz-Mínguez, J.M. Gene expression patterns and dynamics of the colonization of common bean (Phaseolus vulgaris L.) by highly virulent and weakly virulent strains of Fusarium oxysporum. Front. Microbiol. 2015, 6, 234. [CrossRef] [PubMed]

17. Cross, H.; Brick, M.A.; Schwartz, H.F.; Panella, L.W.; Byrne, P.F. Inheritance of Resistance to Fusarium Wilt in Two Common Bean Races. Crop. Sci. 2000, 40, 954-958. [CrossRef]

18. Singh, S.P.; Schwartz, H.F. Breeding common bean for resistance to diseases: A review. Crop. Sci. 2010, 50, 2199-2223. [CrossRef]

19. Paulino, J.F.D.C.; De Almeida, C.P.; Gonçalves, G.D.M.C.; Bueno, C.J.; Carbonell, S.A.M.; Chiorato, A.F.; Bechimol-Reis, L.L. Assessment of resistance in common bean to Fusarium oxysporum $\mathrm{f}$. sp. phaseoli using different inoculation and evaluation methods. Crop. Breed. Appl. Biotechnol. 2020, 20, 2020. [CrossRef]

20. Cruz, A.F.; Silva, L.F.; Sousa, T.V.; Nicoli, A.; de Paula Junior, T.J.; Caixeta, E.T.; Zambolim, L. Molecular diversity in Fusarium oxysporum isolates from common bean fields in Brazil. Eur. J. Plant Pathol. 2018, 152, 343-354. [CrossRef]

21. Petkar, A.; Harris-Shultz, K.; Wang, H.; Brewer, M.T.; Sumabat, L.; Ji, P. Genetic and phenotypic diversity of Fusarium oxysporum f. sp. niveum populations from watermelon in the southeastern United States. PLoS ONE 2019, 14, e0219821. [CrossRef]

22. Ribeiro, R.L.; Hagedorn, D. Screening for Resistance to and Pathogenic Specialization of Fusarium oxysporum f. sp. phaseoli, the Causal Agent of Bean Yellows. Phytopathology 1979, 69, 272-276. [CrossRef]

23. Fall, A.L.; Byrne, P.F.; Jung, G.; Coyne, D.P.; Brick, M.A.; Schwartz, H.F. Detection and mapping of a major locus for fusarium wilt resistance in common bean. Crop. Sci. 2001, 41, 1494-1498. [CrossRef]

24. Cândida, D.V.; Costa, J.G.C.; Rava, C.A.; Carneiro, M.S. Genetic control of Fusarium wilt in common bean. Trop. Plant Pathol. 2009, 34, 379-384. [CrossRef]

25. Leitao, S.T.; Malosetti, M.; Song, Q.; Van Eeuwijk, F.; Rubiales, D.; Vaz Patto, M.C. Natural variation in Portuguese common bean germplasm reveals new sources of resistance against fusarium oxysporum $\mathrm{f}$. sp. phaseoli and resistance-associated candidate genes. Phytopathology 2020, 110, 633-647. [CrossRef] [PubMed]

26. Pereira, T.; Coelho, C.M.; Bogo, A.; Guidolin, A.F.; Miquelluti, D.J. Diversity in common bean landraces from south Brazil. Acta Bot. Croat. 2009, 68, 79-92.

27. Chen, L.; Wu, Q.; He, W.; He, T.; Wu, Q.; Miao, Y. Combined De Novo Transcriptome and Metabolome Analysis of Common Bean Response to Fusarium oxysporum f. sp. phaseoli Infection. Int. J. Mol. Sci. 2019, 20, 6278. [CrossRef]

28. Doerge, R.W. Mapping and analysis of quantitative trait loci in experimental populations. Nat. Rev. Genet. 2002, 3, 43-52. [CrossRef] 
29. Keller, B.; Manzanares, C.; Jara, C.; Lobaton, J.D.; Studer, B.; Raatz, B. Fine-mapping of a major QTL controlling angular leaf spot resistance in common bean (Phaseolus vulgaris L.). Theor. Appl. Genet. 2015, 128, 813-826. [CrossRef]

30. Yu, Z.; Chang, F.; Lv, W.; Sharmin, R.A.; Wang, Z.; Kong, J.; Akhter Bhat, J.; Zhao, T. Identification of QTN and Candidate Gene for Seed-flooding Tolerance in Soybean [Glycine max (L.) Merr.] using Genome-Wide Association Study (GWAS). Genes 2019, 10, 957. [CrossRef]

31. Wang, T.; Wei, L.; Wang, J.; Xie, L.; Li, Y.Y.; Ran, S.; Ren, L.; Lu, K.; Li, J.; Timko, M.P.; et al. Integrating GWAS, linkage mapping and gene expression analyses reveals the genetic control of growth period traits in rapeseed (Brassica napus L.). Biotechnol. Biofuels 2020, 13. [CrossRef]

32. Bartoli, C.; Roux, F. Genome-wide association studies in plant pathosystems: Toward an ecological genomics approach. Front. Plant. Sci. 2017, 8, 8. [CrossRef]

33. Zan, Y.; Carlborg, Ö. A multilocus association analysis method integrating phenotype and expression data reveals multiple novel associations to flowering time variation in wild-collected Arabidopsis thaliana. Mol. Ecol. Resour. 2018, 18, 798-808. [CrossRef] [PubMed]

34. Wang, J.; McClean, P.E.; Lee, R.; Goos, R.J.; Helms, T. Association mapping of iron deficiency chlorosis loci in soybean (Glycine $\max$ L. Merr.) advanced breeding lines. Theor. Appl. Genet. 2008, 116, 777-787. [CrossRef]

35. Wen, L.; Chang, H.X.; Brown, P.J.; Domier, L.L.; Hartman, G.L. Genome-wide association and genomic prediction identifies soybean cyst nematode resistance in common bean including a syntenic region to soybean Rhg1 locus. Hortic. Res. 2019, 6, 1-12. [CrossRef] [PubMed]

36. Oladzad, A.; Zitnick-Anderson, K.; Jain, S.; Simons, K.; Osorno, J.M.; McClean, P.E.; Pasche, J.S. Genotypes and Genomic Regions Associated With Rhizoctonia solani Resistance in Common Bean. Front. Plant Sci. 2019, 10. [CrossRef] [PubMed]

37. De Almeida, C.P.; Paulino, J.F.D.C.; Carbonell, S.A.M.; Chiorato, A.F.; Song, Q.; Di Vittori, V.; Rodriguez, M.; Papa, R.; BenchimolReis, L.L. Genetic Diversity, Population Structure, and Andean Introgression in Brazilian Common Bean Cultivars after Half a Century of Genetic Breeding. Genes 2020, 11, 1298. [CrossRef]

38. Song, Q.; Jia, G.; Hyten, D.L.; Jenkins, J.; Hwang, E.-Y.; Schroeder, S.G.; Osorno, J.M.; Schmutz, J.; Jackson, S.A.; Mcclean, P.E.; et al. SNP Assay Development for Linkage Map Construction, Anchoring Whole-Genome Sequence, and Other Genetic and Genomic Applications in Common Bean. G3 Genes Genomes Genet. 2015. [CrossRef] [PubMed]

39. Cichy, K.A.; Porch, T.G.; Beaver, J.S.; Cregan, P.; Fourie, D.; Glahn, R.P.; Grusak, M.A.; Kamfwa, K.; Katuuramu, D.N.; McClean, P.; et al. A Phaseolus vulgaris diversity panel for andean bean improvement. Crop. Sci. 2015, 55, 2149-2160. [CrossRef]

40. De Lima Castro, S.A.; Gonçalves-Vidigal, M.C.; Gilio, T.A.S.; Lacanallo, G.F.; Valentini, G.; da Silva Ramos Martins, V.; Song, Q.; Galván, M.Z.; Hurtado-Gonzales, O.P.; Pastor-Corrales, M.A. Genetics and mapping of a new anthracnose resistance locus in Andean common bean Paloma. BMC Genom. 2017, 18. [CrossRef]

41. Gonçalves-Vidigal, M.C.; Gilio, T.A.S.; Valentini, G.; Vaz-Bisneta, M.; Vidigal Filho, P.S.; Song, Q.; Oblessuc, P.R.; Melotto, M. New Andean source of resistance to anthracnose and angular leaf spot: Fine-mapping of disease-resistance genes in California Dark Red Kidney common bean cultivar. PLoS ONE 2020, 15, e0235215. [CrossRef]

42. Hurtado-Gonzales, O.P.; Valentini, G.; Gilio, T.A.S.; Martins, A.M.; Song, Q.; Pastor-Corrales, M.A. Fine mapping of Ur-3, a historically important rust resistance locus in common bean. G3 Genes Genomes Genet. 2017, 7, 557-569. [CrossRef]

43. Kamfwa, K.; Cichy, K.A.; Kelly, J.D. Genome-Wide Association Study of Agronomic Traits in Common Bean. Plant Genome 2015, 8, plantgenome2014-09. [CrossRef] [PubMed]

44. Zuiderveen, G.H.; Padder, B.A.; Kamfwa, K.; Song, Q.; Kelly, J.D. Genome-Wide association study of anthracnose resistance in andean beans (Phaseolus vulgaris). PLoS ONE 2016, 11, e0156391. [CrossRef] [PubMed]

45. Bello, M.H.; Moghaddam, S.M.; Massoudi, M.; McClean, P.E.; Cregan, P.B.; Miklas, P.N. Application of in silico bulked segregant analysis for rapid development of markers linked to Bean common mosaic virus resistance in common bean. BMC Genom. 2014, 15, 1-13. [CrossRef] [PubMed]

46. Nakedde, T.; Ibarra-Perez, F.J.; Mukankusi, C.; Waines, J.G.; Kelly, J.D. Mapping of QTL associated with Fusarium root rot resistance and root architecture traits in black beans. Euphytica 2016, 212, 51-63. [CrossRef]

47. Vidigal Filho, P.S.; Gonçalves-Vidigal, M.C.; Vaz Bisneta, M.; Souza, V.B.; Gilio, T.A.S.; Calvi, A.A.; Lima, L.R.L.; PastorCorrales, M.A.; Melotto, M. Genome-wide association study of resistance to anthracnose and angular leaf spot in Brazilian Mesoamerican and Andean common bean cultivars. Crop. Sci. 2020, 60, 2931-2950. [CrossRef]

48. Diniz, A.L.; Giordani, W.; Costa, Z.P.; Margarido, G.R.A.; Perseguini, J.M.K.C.; Benchimol-Reis, L.L.; Chiorato, A.F.; Garcia, A.A.F.; Vieira, M.L.C. Evidence for strong kinship influence on the extent of linkage disequilibrium in cultivated common beans. Genes 2019, 10, 5. [CrossRef]

49. Blair, M.W.; Brondani, R.V.P.; Díaz, L.M.; Del Peloso, M.J. Diversity and Population Structure of Common Bean from Brazil. Crop. Sci. 2013, 53, 1983-1993. [CrossRef]

50. CIMMYT. Laboratory Protocols: CIMMYT Applied Molecular Genetics Laboratory Protocols, 3rd ed.; CIMMYT: Mexico City, Mexico, 2005.

51. Schmutz, J.; McClean, P.E.; Mamidi, S.; Wu, G.A.; Cannon, S.B.; Grimwood, J.; Jenkins, J.; Shu, S.; Song, Q.; Chavarro, C.; et al. A reference genome for common bean and genome-wide analysis of dual domestications. Nat. Genet. 2014, 46, 707-713. [CrossRef]

52. Bradbury, P.J.; Zhang, Z.; Kroon, D.E.; Casstevens, T.M.; Ramdoss, Y.; Buckler, E.S. TASSEL: Software for association mapping of complex traits in diverse samples. Bioinform. Appl. 2007, 23, 2633-2635. [CrossRef] 
53. Browning, B.L.; Zhou, Y.; Browning, S.R. A One-Penny Imputed Genome from Next-Generation Reference Panels. Am. J. Hum. Genet. 2018, 103, 338-348. [CrossRef]

54. Alves-Santos, F.M.; Cordeiro-Rodrigues, L.; Sayagues, J.M.; Martin-Dominguez, R.; Garcia-Benavides, P.; Crespo, M.C.; DiazMinguez, J.M.; Eslava, A.P. Pathogenicity and race characterization of Fusarium oxysporum f. sp. phaseoli isolates from Spain and Greece. Plant Pathol. 2002, 51, 605-611. [CrossRef]

55. Batista, R.O.; E Oliveira, A.M.C.; Silva, J.L.O.; Nicoli, A.; Carneiro, P.C.S.; Júnior, T.J.D.P.; De Queiroz, M.V.; Carneiro, J.E.D.S. Resistance to Fusarium wilt in common bean. Crop. Breed. Appl. Biotechnol. 2016, 16, 226-233. [CrossRef]

56. Pastor-Corrales, M.A.; Abawi, G.S. Reactions of Selected Bean Germ Plasms to Infection by Fusarium oxysporum f. sp. phaseoli. Plant Dis. 1987, 71, 990. [CrossRef]

57. Shaner, G.; Finney, R.E. The effect of nitrogen fertilization on the expression of slow-mildewing resistance in knox wheat. Phytopathology 1997, 70, 1183-1186. [CrossRef]

58. Matias, F.I.; Granato, I.; Fritsche-Neto, R. Be-Breeder: An R/Shiny application for phenotypic data analyses in plant breeding. Crop. Breed. Appl. Biotechnol. 2018, 18, 241-243. [CrossRef]

59. Liu, X.; Huang, M.; Fan, B.; Buckler, E.S.; Zhang, Z. Iterative Usage of Fixed and Random Effect Models for Powerful and Efficient Genome-Wide Association Studies. PLoS Genet. 2016, 12. [CrossRef] [PubMed]

60. Schwarz, G. Estimating the Dimension of a Model. Ann. Stat. 1978, 6, 461-464. [CrossRef]

61. Yu, J.; Pressoir, G.; Briggs, W.H.; Bi, I.V.; Yamasaki, M.; Doebley, J.F.; McMullen, M.D.; Gaut, B.S.; Nielsen, D.M.; Holland, J.B.; et al. A unified mixed-model method for association mapping that accounts for multiple levels of relatedness. Nat. Genet. 2006, 38, 203-208. [CrossRef] [PubMed]

62. VanRaden, P.M. Efficient methods to compute genomic predictions. J. Dairy Sci. 2008, 91, 4414-4423. [CrossRef]

63. Churchill, G.A.; Doerge, R.W. Empirical threshold values for quantitative trait mapping. Genetics 1994, 138, 963-971. [CrossRef]

64. Bonferroni, C. Teoria statistica delle classi e calcolo delle probabilità. Pubblicazioni del R Istituto Superiore di Scienze Economiche e Commericiali di Firenze 1963, 8, 3-62.

65. Dandine-Roulland, C.; Perdry, H. Genome-wide data manipulation, association analysis and heritability estimates in R with Gaston 1.5. Hum. Hered. 2017, 83, 1-29.

66. Hill, W.G.; Weir, B.S. Variances and covariances of squared linkage disequilibria in finite populations. Theor. Popul. Biol. 1988, 33, 54-78. [CrossRef]

67. Goodstein, D.M.; Shu, S.; Howson, R.; Neupane, R.; Hayes, R.D.; Fazo, J.; Mitros, T.; Dirks, W.; Hellsten, U.; Putnam, N.; et al. Phytozome: A comparative platform for green plant genomics. Nucleic Acids Res. 2012, 40. [CrossRef]

68. Augusto Morais Carbonell, S.; Fernando Chiorato, A.; Bolonhezi, D.; Lúcia Paes de Barros, V.N.; Luis Barbosa Borges, W.; Ticelli, M.; Boller Gallo, P.; Luis Finoto, E.; Cristina Belmiro dos Santos, N. 'IAC Milênio'-Common bean cultivar with high grain quality. Crop. Breed. Appl. Biotechnol. 2014, 14, 273-276. [CrossRef]

69. Chiorato, A.F.; Carbonell, S.A.M.; Gonçalves, J.G.R.; da Silva, D.A.; Benchimol-Reis, L.L.; Carvalho, C.R.L.; de Barros, V.L.N.P.; de Freitas, R.S.; Ticelli, M.; Gallo, P.B.; et al. IAC sintonia: New carioca common bean cultivar. Crop. Breed. Appl. Biotechnol. 2018, 18, 338-342. [CrossRef]

70. Mendes, L.W.; Raaijmakers, J.M.; De Hollander, M.; Mendes, R.; Tsai, S.M. Influence of resistance breeding in common bean on rhizosphere microbiome composition and function. ISME J. 2018, 12, 212-224. [CrossRef]

71. Melo, L.C.; Pereira, H.S.; De Faria, L.C.; De Souza, T.L.P.O.; Wendland, A.; Díaz, J.L.C.; De Carvalho, H.W.L.; Da Costa, A.F.; Magaldi, M.C.D.S. BRS FC402: High-yielding common bean cultivar with carioca grain, resistance to anthracnose and fusarium wilt. Crop. Breed. Appl. Biotechnol. 2017, 17, 67-71. [CrossRef]

72. Teixeira, A.; Da Silva, D.A.; Gonçalves, J.G.R.; Esteves, J.A.F.; Carbonell, S.A.M.; Chiorato, A.F. Root characterization of bean genotypes (Phaseolus vulgaris) under drought stress. Genet. Mol. Res. 2019, 18. [CrossRef]

73. Recchia, G.H.; Caldas, D.G.G.; Beraldo, A.L.A.; da Silva, M.J.; Tsai, S.M. Transcriptional analysis of drought-induced genes in the roots of a tolerant genotype of the common bean (Phaseolus vulgaris L.). Int. J. Mol. Sci. 2013, 14, 7155-7179. [CrossRef]

74. Briñez, B.; Perseguini, J.M.K.C.; Rosa, J.S.; Bassi, D.; Gonçalves, J.G.R.; Almeida, C.; Paulino, J.F.D.C.; Blair, M.W.; Chioratto, A.F.; Carbonell, S.A.M.; et al. Mapping QTLs for drought tolerance in a SEA 5 x AND 277 common bean cross with SSRs and SNP markers. Genet. Mol. Biol. 2017, 40, 813-823. [CrossRef]

75. Gonçalves, J.G.R.; de Andrade, E.R.; da Silva, D.A.; de Fátima Esteves, J.A.; Chiorato, A.F.; Carbonell, S.A.M. Drought tolerance evaluated in common bean genotypes. Ciência Agrotecnologia 2019, 43, 1719. [CrossRef]

76. Bush, W.S.; Moore, J.H. Chapter 11: Genome-Wide Association Studies. PLoS Comput. Biol. 2012, 8, e1002822. [CrossRef]

77. Fritsche-Neto, R.; De Souza, T.L.P.O.; Pereira, H.S.; De Faria, L.C.; Melo, L.C.; Novaes, E.; Brum, I.J.B.; Jannink, J.L. Association mapping in common bean revealed regions associated with anthracnose and angular leaf spot resistance. Sci. Agric. 2019, 76, 321-327. [CrossRef]

78. Blair, M.W.; Cortés, A.J.; Farmer, A.D.; Huang, W.; Ambachew, D.; Varma Penmetsa, R.; Carrasquilla-Garcia, N.; Assefa, T.; Cannon, S.B. Uneven recombination rate and linkage disequilibrium across a reference SNP map for common bean (Phaseolus vulgaris L.). PLoS ONE 2018, 13, e0189597. [CrossRef]

79. Korte, A.; Farlow, A. The advantages and limitations of trait analysis with GWAS: A review. Plant Methods 2013, 9, 29. [CrossRef] [PubMed]

80. Henrique, F.H.; Carbonell, S.A.M.; Ito, M.F.; Gonçalves, J.G.R.; Sasseron, G.R.; Chiorato, A.F. Classification of physiological races of Fusarium oxysporum f. sp. phaseoli in common bean. Bragantia 2015, 74, 84-92. [CrossRef] 
81. Sasseron, G.R.; Benchimol-Reis, L.L.; Perseguini, J.M.K.C.; Paulino, J.F.C.; Bajay, M.M.; Carbonell, S.A.M.; Chiorato, A.F. Fusarium oxysporum f. sp. phaseoli genetic variability assessed by new developed microsatellites. Genet. Mol. Biol. 2020, 43. [CrossRef]

82. Alves-Santos, F.M.; Benito, E.P.; Eslava, A.P.; Díaz-Mínguez, J.M. Genetic diversity of Fusarium oxysporum strains from common bean fields in Spain. Appl. Environ. Microbiol. 1999, 65, 3335-3340. [CrossRef]

83. Jiménez-Gasco, M.M.; Milgroom, M.G.; Jiménez-Díaz, R.M. Gene genealogies support Fusarium oxysporum f. sp. ciceris as a monophyletic group. Plant Pathol. 2002, 51, 72-77. [CrossRef]

84. Lv, H.; Fang, Z.; Yang, L.; Zhang, Y.; Wang, Y. An update on the arsenal: Mining resistance genes for disease management of Brassica crops in the genomic era. Hortic. Res. 2020, 7, 34. [CrossRef] [PubMed]

85. Jha, U.C.; Bohra, A.; Pandey, S.; Parida, S.K. Breeding, Genetics, and Genomics Approaches for Improving Fusarium Wilt Resistance in Major Grain Legumes. Front. Genet. 2020, 11, 1001. [CrossRef] [PubMed]

86. Rep, M.; Kistler, H.C. The genomic organization of plant pathogenicity in Fusarium species. Curr. Opin. Plant. Biol. 2010, 13, 420-426. [CrossRef]

87. Thaines Bodah, E. Root Rot Diseases in Plants: A Review of Common Causal Agents and Management Strategies. Agric. Res. Technol. Open Access J. 2017, 5. [CrossRef]

88. Gupta, A.; Sarkar, A.K.; Senthil-Kumar, M. Global transcriptional analysis reveals unique and shared responses in arabidopsis thaliana exposed to combined drought and pathogen stress. Front. Plant. Sci. 2016, 7. [CrossRef]

89. Kumaran, D.; Eswaramoorthy, S.; Studier, F.W.; Swaminathan, S. Structure and mechanism of ADP-ribose-1"-monophosphatase (Appr-1"-pase), a ubiquitous cellular processing enzyme. Protein Sci. 2005, 14, 719-772. [CrossRef]

90. Devoto, A.; Muskett, P.R.; Shirasu, K. Role of ubiquitination in the regulation of plant defence against pathogens. Curr. Opin. Plant. Biol. 2003, 6, 307-311. [CrossRef]

91. Lyzenga, W.J.; Stone, S.L. Abiotic stress tolerance mediated by protein ubiquitination. J. Exp. Bot. 2012, 63, 599-616. [CrossRef]

92. Lee, J.H.; Kim, W.T. Regulation of abiotic stress signal transduction by E3 ubiquitin ligases in arabidopsis. Mol. Cells 2011, 31, 201-208. [CrossRef]

93. Lim, C.W.; Baek, W.; Jung, J.; Kim, J.H.; Lee, S.C. Function of ABA in stomatal defense against biotic and drought stresses. Int. J. Mol. Sci. 2015, 16, 15251-15270. [CrossRef]

94. Mao, G.; Seebeck, T.; Schrenker, D.; Yu, O. CYP709B3, a cytochrome P450 monooxygenase gene involved in salt tolerance in Arabidopsis thaliana. BMC Plant Biol. 2013, 13, 169. [CrossRef] [PubMed]

95. Xu, J.; Wang, X.Y.; Guo, W.Z. The cytochrome P450 superfamily: Key players in plant development and defense. J. Integr. Agric. 2015, 14, 1673-1686. [CrossRef]

96. Sun, X.; Gilroy, E.M.; Chini, A.; Nurmberg, P.L.; Hein, I.; Lacomme, C.; Birch, P.R.J.; Hussain, A.; Yun, B.W.; Loake, G.J. ADS1 encodes a MATE-transporter that negatively regulates plant disease resistance. New Phytol. 2011, 192, 471-482. [CrossRef]

97. Shoji, T.; Inai, K.; Yazaki, Y.; Sato, Y.; Takase, H.; Shitan, N.; Yazaki, K.; Goto, Y.; Toyooka, K.; Matsuoka, K.; et al. Multidrug and toxic compound extrusion-type transporters implicated in vacuolar sequestration of nicotine in tobacco roots. Plant Physiol. 2009, 149, 708-718. [CrossRef]

98. Zhao, J.; Dixon, R.A. MATE transporters facilitate vacuolar uptake of epicatechin $3^{\prime}$-O-glucoside for proanthocyanidin biosynthesis in medicago truncatula and arabidopsis. Plant Cell 2009, 21, 2323-2340. [CrossRef]

99. Debeaujon, I.; Peeters, A.J.M.; Léon-Kloosterziel, K.M.; Koornneef, M. The transparent testa12 gene of Arabidopsis encodes a multidrug secondary transporter-like protein required for flavonoid sequestration in vacuoles of the seed coat endothelium. Plant Cell 2001, 13, 853-871. [CrossRef]

100. Pérez-Díaz, R.; Ryngajllo, M.; Pérez-Díaz, J.; Peña-Cortés, H.; Casaretto, J.A.; González-Villanueva, E.; Ruiz-Lara, S. VvMATE1 and VvMATE2 encode putative proanthocyanidin transporters expressed during berry development in Vitis vinifera L. Plant Cell Rep. 2014, 33, 1147-1159. [CrossRef] [PubMed]

101. Zhang, H.; Zhu, H.; Pan, Y.; Yu, Y.; Luan, S.; Li, L. A DTX/MATE-type transporter facilitates abscisic acid efflux and modulates ABA sensitivity and drought tolerance in Arabidopsis. Mol. Plant 2014, 7, 1522-1532. [CrossRef] [PubMed]

102. Mandal, S.; Mallick, N.; Mitra, A. Salicylic acid-induced resistance to Fusarium oxysporum f. sp. lycopersici in tomato. Plant. Physiol. Biochem. 2009, 47, 642-649. [CrossRef]

103. Sharma, M.; Pandey, G.K. Expansion and function of repeat domain proteins during stress and development in plants. Front. Plant Sci. 2016, 6, 1218. [CrossRef] [PubMed]

104. Yin, Y.; Huang, J.; Xu, Y. The cellulose synthase superfamily in fully sequenced plants and algae. BMC Plant Biol. 2009, 9, 99. [CrossRef] [PubMed]

105. Ortiz, E.; Cruz, M.; Melgarejo, L.M.; Marquínez, X.; Hoyos-Carvajal, L. Características hispatologicas da infecção causada por Fusarium oxysporum e F. solani em maracujá-roxo (Passiflora edulis Sims). Summa Phytopathologica. Summa Phytopathol. 2014, 40, 134-140. [CrossRef]

106. Gupta, S.K.; Rai, A.K.; Kanwar, S.S.; Sharma, T.R. Comparative analysis of zinc finger proteins involved in plant disease resistance. PLoS ONE 2012, 7, e42578. [CrossRef]

107. Noman, A.; Aqeel, M.; Khalid, N.; Islam, W.; Sanaullah, T.; Anwar, M.; Khan, S.; Ye, W.; Lou, Y. Zinc finger protein transcription factors: Integrated line of action for plant antimicrobial activity. Microb. Pathog. 2019, 132, 141-149. [CrossRef] [PubMed]

108. Wang, X.; Cai, X.; Xu, C.; Wang, Q.; Dai, S. Drought-responsive mechanisms in plant leaves revealed by proteomics. Int. J. Mol. Sci. 2016, 17, 1706. [CrossRef] 
109. Singh, D.; Yadav, N.S.; Tiwari, V.; Agarwal, P.K.; Jha, B. A SNARE-Like Superfamily Protein SbSLSP from the Halophyte Salicornia brachiata Confers Salt and Drought Tolerance by Maintaining Membrane Stability, K+/Na+ Ratio, and Antioxidant Machinery. Front. Plant Sci. 2016, 7, 737. [CrossRef] [PubMed]

110. Erfatpour, M.; Navabi, A.; Pauls, K.P. Mapping the non-darkening trait from 'Wit-rood boontje' in bean (Phaseolus vulgaris). Theor. Appl. Genet. 2018, 131, 1331-1343. [CrossRef] [PubMed]

111. Brick, M.A.; Byrne, P.F.; Schwartz, H.F.; Ogg, J.B.; Otto, K.; Fall, A.L.; Gilbert, J. Reaction to three races of fusarium wilt in the Phaseolus vulgaris core collection. Crop. Sci. 2006, 46, 1245-1252. [CrossRef]

112. Banoo, A.; Nabi, A.; Rasool, R.S.; Farooq, M.; Shah, M.D.; Ahmad, M.; Sofi, P.A.; Nabi, A.; Itoo, H.; Sharma, P.N.; et al. NorthWestern Himalayan Common Beans: Population Structure and Mapping of Quantitative Anthracnose Resistance Through Genome Wide Association Study. Front. Plant Sci. 2020, 11, 1. [CrossRef]

113. Bisneta, M.V.; Gonçalves-Vidigal, M.C. Integration of anthracnose resistance loci and RLK and NBS-LRR-encoding genes in the Phaseolus vulgaris L. genome. Crop. Sci. 2020. [CrossRef]

114. Oladzad, A.; Porch, T.; Rosas, J.C.; Moghaddam, S.M.; Beaver, J.; Beebe, S.E.; Burridge, J.; Jochua, C.N.; Miguel, M.A.; Miklas, P.N.; et al. Single and multi-trait GWAS identify genetic factors associated with production traits in common bean under abiotic stress environments. G3 Genes Genomes Genet. 2019, 9, 1881-1892. [CrossRef]

115. Steele, J.F.C.; Hughes, R.K.; Banfield, M.J. Structural and biochemical studies of an NB-ARC domain from a plant NLR immune receptor. PLOS ONE 2019, 14, e0221226. [CrossRef]

116. Hoyos-Villegas, V.; Song, Q.; Kelly, J.D. Genome-wide Association Analysis for Drought Tolerance and Associated Traits in Common Bean. Plant Genome 2017, 10, plantgenome2015-12. [CrossRef]

117. Myers, J.R.; Wallace, L.T.; Moghaddam, S.M.; Kleintop, A.E.; Echeverria, D.; Thompson, H.J.; Brick, M.A.; Lee, R.; McClean, P.E. Improving the health benefits of snap bean: Genome-wide association studies of total phenolic content. Nutrients 2019, 11, 2509. [CrossRef] [PubMed]

118. Freixas Coutin, J.A.; Munholland, S.; Silva, A.; Subedi, S.; Lukens, L.; Crosby, W.L.; Pauls, K.P.; Bozzo, G.G. Proanthocyanidin accumulation and transcriptional responses in the seed coat of cranberry beans (Phaseolus vulgaris L.) with different susceptibility to postharvest darkening. BMC Plant Biol. 2017, 17, 89. [CrossRef]

119. Zur, I.A.; Dubas, E.; Pociecha, E.; Dubert, F.; Kolasińska, I.; Płazek, A. Cytological analysis of infection process and the first defence responses induced in winter rye (Secale cereale L.) seedlings inoculated with Microdochium nivale. Physiol. Mol. Plant Pathol. 2011, 76, 189-196. [CrossRef]

120. Piasecka, A.; Jedrzejczak-Rey, N.; Bednarek, P. Secondary metabolites in plant innate immunity: Conserved function of divergent chemicals. New Phytol. 2015, 206, 948-964. [CrossRef]

121. Leitão, S.T.; Araújo, S.; Rubiales, D.; Vaz Patto, M.C. Abiotic and Biotic Stresses Interaction in Fabaceae Plants. Contributions from the Grain Legumes/Soilborne Vascular Diseases/Drought Stress Triangle. In The Plant Family Fabaceae; Springer: Singapore, 2020; pp. 237-260.

122. Aung, K.; Jiang, Y.; He, S.Y. The role of water in plant-microbe interactions. Plant J. 2018, 93, 771-780. [CrossRef] [PubMed]

123. Xue, R.; Wu, J.; Zhu, Z.; Wang, L.; Wang, X.; Wang, S.; Blair, M.W. Differentially Expressed Genes in Resistant and Susceptible Common Bean (Phaseolus vulgaris L.) Genotypes in Response to Fusarium oxysporum f. sp. phaseoli. PLoS ONE 2015, 10, e0127698. [CrossRef]

124. Bigeard, J.; Colcombet, J.; Hirt, H. Signaling mechanisms in pattern-triggered immunity (PTI). Mol. Plant 2015, 8, 521-539. [CrossRef] 